Eastern Illinois University

The Keep

Masters Theses

Student Theses \& Publications

2015

\title{
Researching the Historical Representations of Andrew Jackson in Trade Books
}

Steven K. Sakowicz

Eastern Illinois University

This research is a product of the graduate program in Early Childhood, Elementary, and Middle Level

Education at Eastern Illinois University. Find out more about the program.

\section{Recommended Citation}

Sakowicz, Steven K., "Researching the Historical Representations of Andrew Jackson in Trade Books" (2015). Masters Theses. 2389.

https://thekeep.eiu.edu/theses/2389

This is brought to you for free and open access by the Student Theses \& Publications at The Keep. It has been accepted for inclusion in Masters Theses

by an authorized administrator of The Keep. For more information, please contact tabruns@eiu.edu. 


\section{The Graduate Schoor In}

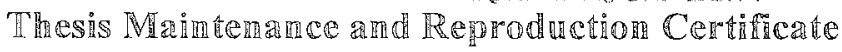

FOR: Graduate Candidates Completing Theses in Partial Fulfillment of the Degree
Graduate Faculty Advisors Directing the Theses

RE: $\quad$ Preservation, Reproduction, and Distribution of Thesis Research

Preserving, reproducing, and distributing thesis research is an important part of Booth Library's responsibility to provide access to scholarship. In order to further this goal, Booth Library makes all graduate theses completed as part of a degree program at Eastern Illinois University available for personal study, research, and other not-for-profit educational purposes. Under 17 U.S.C. $\$ 108$, the library may reproduce and distribute a copy without infringing on copyright; however, professional courtesy dictates that permission be requested from the author before doing so.

Your signatures affirm the following:

- The graduate candidate is the author of this thesis.

- The graduate candidate retains the copyright and intellectual property rights associated with the original research, creative activity, and intellectual or artistic content of the thesis.

- The graduate candidate certifies her/his compliance with federal copyright law (Title 17 of the U. $\mathrm{S}$. Code) and her/his right to authorize reproduction and distribution of all copyrighted materials included in this thesis.

a The graduate candidate in consultation with the faculty advisor grants Booth Library the nonexclusive, perpetual right to make copies of the thesis freely and publicly available without restriction, by means of any current or successive technology, including by not limited to photocopying, microfilm, digitization, or internet.

- The graduate candidate acknowledges that by depositing her/his thesis with Booth Library, her/his work is available for viewing by the public and may be borrowed through the library's circulation and interlibrary loan departments, or accessed electronically.

- The graduate candidate waives the confidentiality provisions of the Family Educational Rights and Privacy Act (FERPA) (20 U. S. C. $\$ 1232$ g; 34 CFR Part 99) with respect to the contents of the thesis and with respect to information concerning authorship of the thesis, including name and status as a student at Eastern Illinois University.

I have conferred with my graduate faculty advisor. My signature below indicates that I have read and agree with the above statements, and hereby give my permission to allow Booth Library to reproduce and distribute my thesis. My adviser's signature indicates concurrence to peproduce and distribute the thesis.

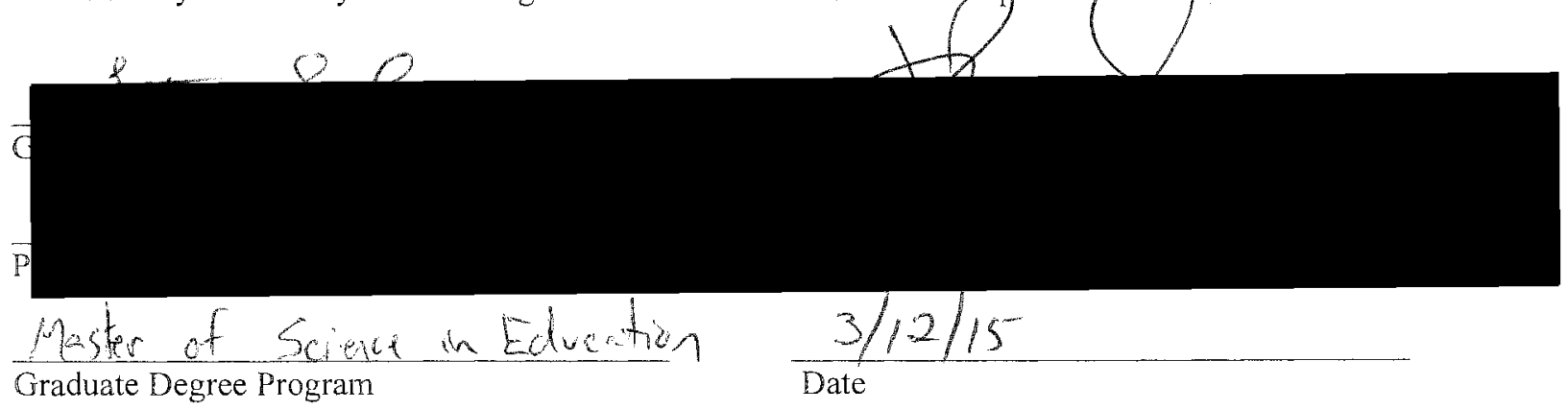

Please submit in duplicate. 
Researching the Historical Representations

of Andrew Jackson in Trade Books

(TITLE)

BY

Steven K. Sakowicz

\section{THESIS}

SUBMITTED IN PARTIAL FULFILLMENT OF THE REQUIREMENTS FOR THE DEGREE OF

\section{Master of Science in Education}

IN THE GRADUATE SCHOOL, EASTERN ILLINOIS UNIVERSITY CHARLESTON, ILLINOIS

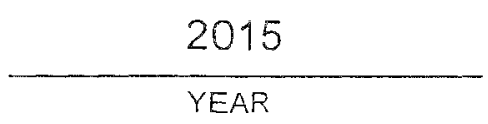

I HEREBY RECOMMEND THAT THIS THESIS BE ACCEPTED AS FULFILLING THIS PART OF THE GRADUATE DEGREE CITED ABOVE

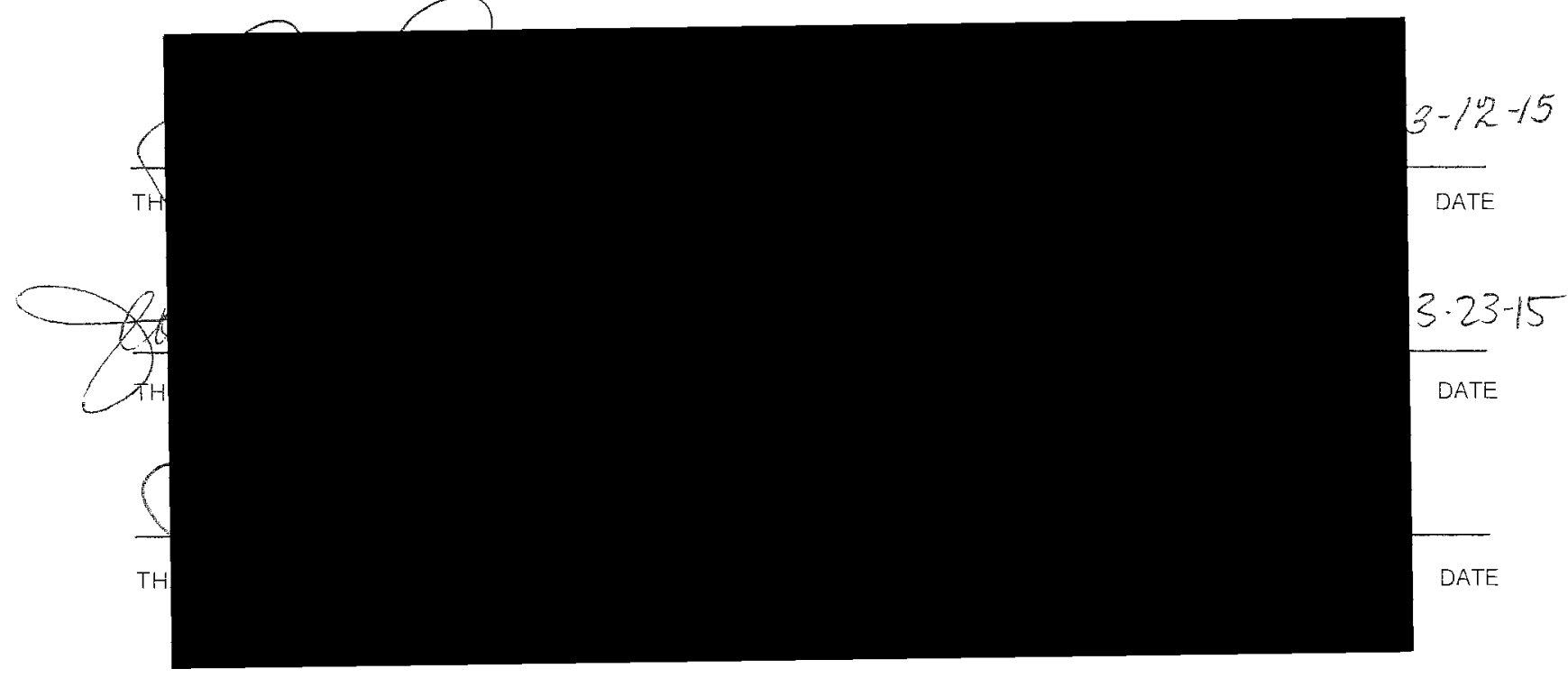


Running head: REPRESENTATIONS OF ANDREW JACKSON IN TRADE BOOKS 1

Researching the Historical Representations of Andrew Jackson in Trade Books

Steven K. Sakowicz

Eastern Illinois University 


\begin{abstract}
State and national standards compel teachers to introduce historical topics through multiple diverse texts, emphasizing the use of informational texts. Trade books allow teachers to meet these standards while also meeting the needs of diverse students. Primary sources serve as an additional curricular resource that fill the gaps in information covered by textbooks and trade books, allowing students to gain a more complete and accurate understanding of historical figures and events. Standards leave the selection and implementation of appropriate trade books, primary sources, and other curricular resources to the classroom teacher. In this research I qualify and quantify how Andrew Jackson is portrayed in trade books. Misrepresentations within trade books concerning Jackson are reported and analyzed. This empirical research guides educators in selecting books for teaching about Jackson, a controversial historical figure. Suggestions and rationale for trade book and primary source selection and implementation are addressed.
\end{abstract} Keywords: Andrew Jackson, trade books, informational texts, primary sources 
I would like to thank Dr. John Bickford for his professional and personal support throughout this process. 
Table of Contents

Researching the Historical Representations of Andrew Jackson in Trade Books.........7

Literature Review ..........................................................

Curricular Resources Used for History Instruction.............................

Primary Source Use in the Classroom........................... 8

Textbook Use in the Classroom.....................................8

Trade Book Use in the Classroom................................10

The Historiography of Andrew Jackson.................................. 12

Democracy.................................................

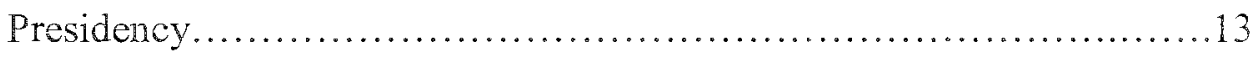

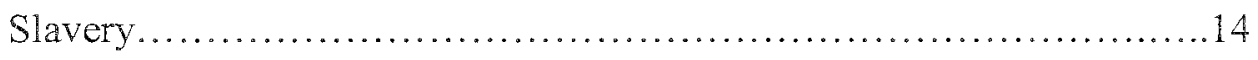

Native American Removal..................................... 15

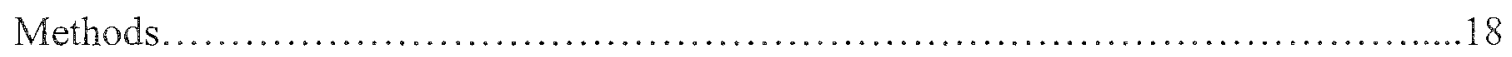

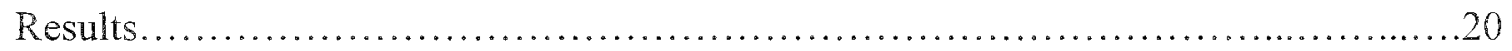

Book Series and Publication Date...................................... 21

Grade Level and Book Genre.......................................23

Primary Sources...................................................... 28

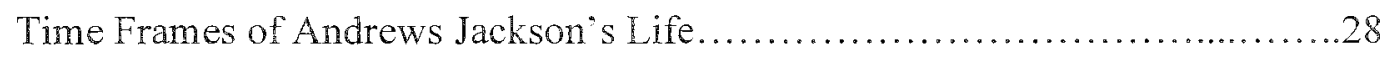

Andrew Jackson's Views on Slavery ................................... 30

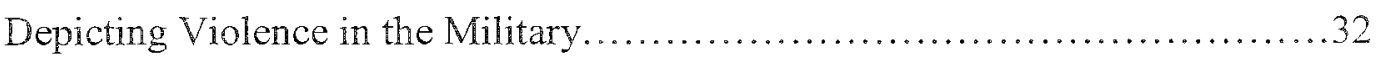

Native Americans..................................................... 34

A Different Kind of President......................................... 35

Jacksonian Democracy............................................... 37 


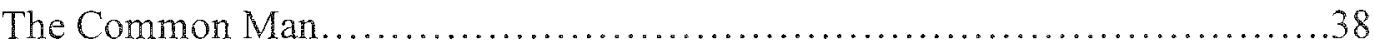

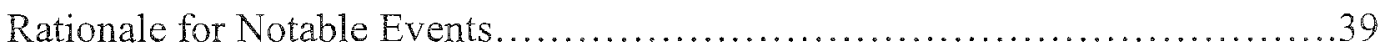

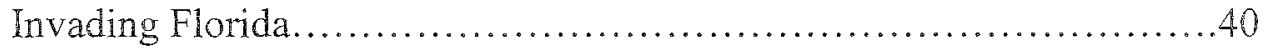

Native American Removal........................................41

Nullification Crisis..............................................42

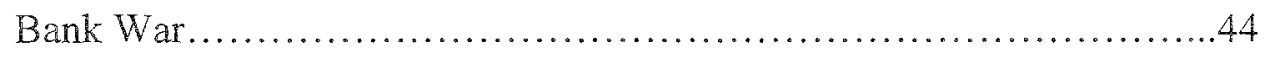

Presence of Common Historical Misrepresentations................................ 45

Heroification.....................................................46

Omission.............................................................. 47

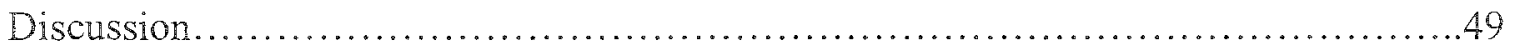

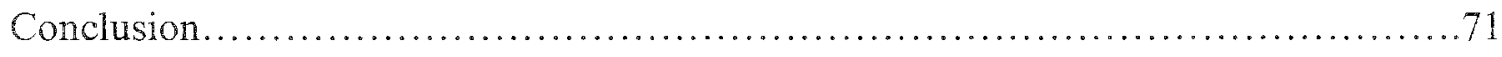

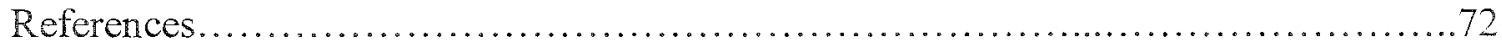

Trade Books on Andrew Jackson.......................................... 78

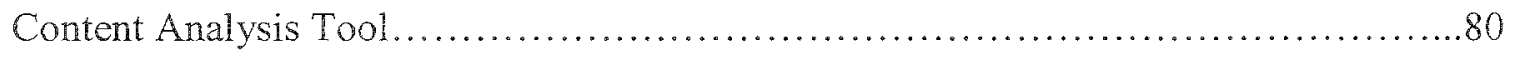

Andrew Jackson's Message on Removal............................................ 82 


\section{List of Tables}

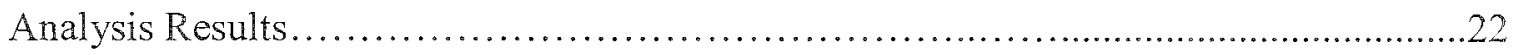

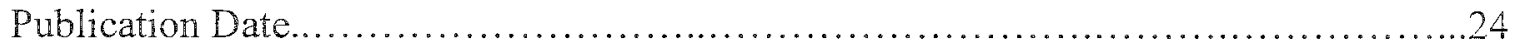

Publication Date with Intended Grade Level.....................................25

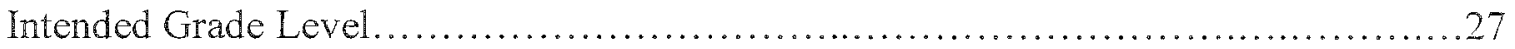


Researching the Historical Representations of Andrew Jackson in Trade Books A polarizing figure as much today as in his time, Andrew Jackson is a historical figure that historians view from different perspectives. Students, however, do not rely on the dense historiography but on trade book and textbook authors' condensed versions. The position of trade books in curriculum only increases as state and national initiatives compel teachers to use multiple and diverse texts. It is important, therefore, to examine how authors of children's and young adult literature choose to represent Jackson in light of historians" perspectives on his life and career. The method of research implemented for this study and its findings is intended to aid teachers in making informed decisions regarding the selection of appropriate literature to supplement classroom teaching.

\section{Literature Review}

Emerging state and national standards and frameworks for college and career readiness serve as benchmarks for student achievement as each student progresses though the United States" education system. Schools and educators are given the "ends" for student development, but with no set "means" for achieving these goals there is freedom for schools and educators to create their own paths for student success (Newman \& Roskos, 2013; Sapers, 2015). One area where educators can diversify instruction and enhance student learning is through the careful selection of curricular resources. These supplementary resources can create and promote a leaming environment that gives students the opportunity to think critically about topies in English and language arts, as well as in content areas such as history and social studies.

\section{Curricular Resources Used for History Instruction}


National standards advocate the reading of informational texts in history, social studies, and English and language arts curriculum (Common Core State Standards Initiative [CCSSI], 2010). To meet these expectations teachers utilize textbooks, trade books, and primary resources (Bickford \& Rich, 2014b). An overview of these curricular resources demonstrates the successes and challenges that can transpire during implementation.

Primary Source Use in the Classroom. Historians use primary sources to compare and contrast different perspectives, form opinions about history, and develop narratives. When teachers introduce primary sources into a history lesson, they give students the opportunity to make inferences about topics in history, going beyond just learning dates and facts (Barksdale, 2013). Primary sources might introduce students to a perspective that contradicts what they had learned previously, or help students to see relationships among facts, thus enhancing the knowledge students are gaining in the classroom and providing opportunities for historical thinking (Barksdale, 2013). A history teacher, however, who is not aware of where or how to locate primary sources, does not have the means to access primary sources, or does not have knowledge of how to effectively evaluate or utilize primary sources to supplement classroom instruction, may rely solely on a history textbook.

Textbook Use in the Classroom. History textbooks are present in many middle school social studies classrooms, and these textbooks can be conducive to satisfactory history instruction (Loewen, 1995). Students rely on facts from these textbooks and trust their content (Loewen, 2010; Schwebel, 2011; Wineburg, 2001). Educators, furthermore, 
give much credence to the historical accuracy of their textbooks (Loewen, 1995; Wineburg, 2001). History textbooks, however, come with potential issues.

The self-censorship of history textbooks has been a contentious topic for decades (Matusevich, 2006.) Publishing companies capitulate to the concerns of special interest groups with the desire of avoiding controversies (Chick, 2006; Matusevich, 2006). The quality of writing suffers as writers are given little leeway to skillfully construct prose with historical scholarship (Matusevich, 2006), resulting in narratives that can be mundane to students (Sewall, 2000; as cited in Matusevich, 2006). Even history textbooks that garnered high praise from historians struggle for publication due to publishers" concerns over content that special interest groups view as disagreeable or contentious (Fitzgerald, 2009; Matusevich, 2006).

With history textbooks expected to cover the breadth of significant time spans, many perspectives are lost due to the constraints placed upon history textbook length (Fitzgerald, 2009). James Loewen (1995) has convincingly argued that the lessons that emerge in textbooks tend to follow a conservative ideology that overlooks the perspectives of minority groups.

Opportunities arise from imbalances. By focusing on identification of bias within history textbooks, social studies teachers can facilitate discussions with middle school students concerning a wide variety of topics (Chick, 2006; Fitzgerald, 2009; Loewen, 1995). In other words, teachers can enable students to scrutinize their historical textbooks for misrepresentations. Such analysis and the subsequent dialogue could prove engaging and productive for students, but the fact remains that although history textbooks can be a resource for teachers, they are not the de facto curriculum (Chick, 2006). There 
are other avenues that middle level social studies teachers can pursue while keeping topics germane to middle level curriculum.

Trade Book Use in the Classroom. State and national initiatives prescribe the use of multiple informational texts in the class such as textbooks, trade books, and primary sources (CCSSI; National Council for the Social Studies [NCSS], 2013; Partnership for Assessment of Readiness for College and Careers [PARCC], 2012). Also, with the requirement that half of students' readings in English and language arts to be informational texts (CCSSI, 2010), educators use trade books to supplement textbooks (Bickford \& Rich, 2014b). Historical fiction and non-fiction trade books are seen in middle school language arts and social studies classrooms, exposing students to historical events that are likely to be overlooked otherwise (Schwebel, 2011; Williams, 2009).

Children's and young adult literature provide social studies teachers with secondary historical sources written at various reading levels, which in turn enables the teacher to select a work that is developmentally appropriate for specific students (Bickford \& Rich, 2014b; Schwebel, 2011). Opportunities for interdisciplinary instruction also arise as English and language arts teachers can use trade books with a social studies theme to teach language arts (Henning, Snow-Gerono, Reed, \& Warner, 2006).

Trade books are apt to attract students' attention with their engaging prose, detail, and narrow coverage (Bickford \& Rich, 2014b; Schwebel, 2011). Trade books, written at various levels with diverse narratives, provide opportunities for teachers to differentiate according to the students' ability and interest (Chick \& Hong 2012; Schwebel, 2011). While normally implemented for students at the primary level, teachers of social studies 
and English at the intermediate and middle level can use these books as a stimulus for exploration of more complex issues (Chick \& Hong, 2012; Schwebel, 2011).

The research on trade books has shown, however, inconsistencies in how topics are presented, and various historical misrepresentations (Bickford, 2013a; Bickford \& Rich, 2014a; Bickford \& Rich, 2014b; Schwebel, 2011; Williams, 2009). Depending on intended audience, the narratives presented by children's authors and historians diverge and converge (Bickford \& Rich, 2014b). The more straightforward prose and syntax that make children's and young adult literature age-appropriate can result in incomplete historical content (Bickford \& Rich, 2014b; Schwebel, 2011; Williams, 2009). Thus, in an ironic twist, age appropriate content and attractive narrative that elicits students' attention to trade books increases the chances of inauthentic history (Bickford \& Rich, 2014a). As a result, not only are opportunities for connections diminished, but middle level students may develop inaccurate or incomplete understandings (Bickford \& Rich, $2014 b)$.

Through investigation of trade books, social studies teachers can guide students to distinguish author bias (Henning et al., 2006). Using multiple trade books that cover the same topic allows students to see different perspectives, initiating thinking about issues of historical representations (Bickford \& Rich, 2014a; Schwebel, 2011). Trade books that incorporate opposing viewpoints provide the opportunity for balanced perspectives as well fostering students' abilities to make connections to real-life (Henning et al., 2006). In terms of gender balance, for example, social studies teachers can compensate for a deficiency of gender balance in history textbooks by supplementing the teaching of history textbooks with the reading of children's and young adult literature (Chick, 2006). 
A trade book cannot be expected to be the quintessential resource for teachers in the classroom, but with historical connections and students' learning at stake, trade books that teachers implement as curricular materials need to be evaluated for historic authenticity (Bickford \& Rich, 2014b). Trades books about Andrew Jackson fit the requirements for this evaluation, as he is a figure who can be written about in many different ways.

\section{The Historiography of Andrew Jackson}

Andrew Jackson is introduced to middle level social studies students as a frontier general who defeated the Creek Native Americans at the Battle of Horseshoe Bend and British soldiers in the Battle of New Orleans (Appleby, Brinkley, Broussard, McPherson, \& Ritchie, 2009; Davidson, \& Stoff, 2011). Jackson reappears as a president that promoted the welfare of the white man, removed Native Americans to the west of the Mississippi River, and used presidential powers to battle the Bank of the United States and preserve the Union during the Nullification Crisis with South Carolina (Appleby et a1., 2009; Davidson, \& Stoff, 2011). History education scholars deem such content significant for middle level social studies curricula.

Andrew Jackson's impact on the United States Presidency, democracy, slavery, and the removal of Native Americans are topics where historians of the past and present have divergent views. Historians offer a range of perspectives on Jackson, and while some perspectives encourage abhorrence and animosity towards Jackson, others foster empathy for Jackson's ideas and actions among those intrigued by Jackson's state of affairs. 
Democracy. Historians debate how much recognition Jackson deserves for the rise of democracy and as a symbol for the common man. A celebratory viewpoint in regards to Jackson, coming from his foremost biographer Robert Remini (1988a), is that the process of democratization was not streamlined until Jackson's emergence in national politics during the presidential election of 1824 . Jackson and his supporters believed it was the right of the American people to elect a president (Remini, 1988a). Public meetings and delegate conventions favored by Jackson supporters over caucusing resulted in increased levels of political interest and participation by everyday Americans (Coens, 2013).

Democratization of the United States during the presidency of Andrew Jackson, however, was the culmination of decades of Americans preparing the republic for a democratic leader (Coens, 2013; Wilentz, 2005). Richard Hofstadter (1948) argued Jackson's ascendancy to the presidency in 1828 , consequently, emanated from the democratization of the United States, instead of being a harbinger of the rise of democracy (as cited in Sacher, 2013). Also, it is important to note that during this time not only did suffrage not extend to include minority groups such as African-Americans, Native Americans, and women, but these groups in fact saw their role in the democratic process diminished (Cole, 2009). Never did it cross Jackson's mind that these minority groups should be allowed the same rights as white men (Remini, 1988a).

Presidency. Andrew Jackson's role in expanding the power of the presidency is associated with his actions during the battle with the Second Bank of the United States. The bank war has been classified as a class conflict (Schlesinger, 1946; Sellers, 1991; as cited in Mihm, 2013), as a conflict between new and old capitalists (Hofstadter, 1948; as 
cited in Mihm, 2013), and also as the triumph of Jacksonian Democracy against the alleged evils the bank presented such as the consolidation of power, economic instability, and corruption (Meyers, 1957; as cited in Mihm, 2013).

Though Arthur Schlesinger Jr. (1946) concluded that Andrew Jackson's veto of the bill that would renew the bank's charter signified Jackson's stand for the rights of the common man (as cited in Mihm, 2013), a conflicting perception hails the veto as the work of a demagogue (Hammond, 1957), who did not understand the intricacies of the bank conflict (Hammond, 1957; as cited in Mihm, 2013). Regardless of perspective, through the destruction of the Second Bank of the United States, Jackson "strengthened the presidency, redefined its role, and profoundly altered its relationship to the people" (Remini, 1967, p. 148).

Slavery. Although the controversy over slavery had not yet achieved the impetus it would garner in the 1840 s and 1850 s, there is debate about how the politics of slavery affected Jackson's motives, his presidency, and the Democratic Party. One perspective is that the demands of slaveholders contributed to Jackson's motives for making treaties with Native Americans and invading Florida (Loewen, 1995). Once land boundaries were settled, the problems of runaway slaves to Native American and foreign lands would be averted (Loewen, 1995). Also, his attempt as president to censor mail that was deemed likely to promote slave uprisings added to the perceived ties between Jackson's Democratic Party and the defense of slavery (Wilentz, 2005).

Though on the surface the Nullification Crisis was centered on tariffs, it has been posited that the underlying issue was slavery (Meacham, 2008). If the federal government could enforce a tariff on southern states, it could then also impose itself in 
regards to the issue of slavery (Freehling, 1965). Remini (1988a) rebuts the idea of slavery being an issue in the Nullification Crisis, stating if slavery was indeed a factor, other southern states would have come to the aid of South Carolina. There is no doubt, however, that Andrew Jackson and the leaders of the Democratic Party were unrepentant slaveholders. Jackson held racist views about slaves, and believed that they were property recognized by the United States Constitution (Remini, 1988a).

Native American Removal. Native American removal is a touchstone for many historians regarding Andrew Jackson. It can be argued that Jackson's approach towards Native American removal was derived from Thomas Jefferson's proposed removal policy (Garrison, 2013). Jefferson formulated a plan to open up the Native American lands to American farmers (Garrison, 2013; Prucha, 1969); furthermore, the Compact of 1802 resulted in Georgia ceding land with assurance that the federal government would make Native American lands available in the future (Garrison, 2013). As a result, by the time Jackson assumed the office of the presidency, many southern politicians and judges pushed the federal government towards removal, propelling Jackson to carry out the policy (Garrison, 2013). Jackson's choices therefore cohered with and were influenced by the public he was serving and his predecessors. The larger part of the American public at this time, in addition, due to their racist views of Native Americans and appetite for land, approved of Jackson's policy (Remini, 2001).

Francis Paul Prucha, a historian of Native Americans, focused on this American public, namely American settlers on the frontier, in his account of Andrew Jackson's motives for removal, which suggests that Jackson concluded that if Native Americans were allowed to stay on their tribal grounds, the government would not have the 
wherewithal to keep American settlers from squating on Native American lands, or the capacity to contain the violence that stemmed from it (Prucha, 1969). Only when the Native Americans relocated west of the Mississippi River would they be capable of pursuing methods of civilization at their own pace or continue the practice of their native customs, free from the imposition of American settlers (Prucha, 1969).

Remini (2001) echoes this sentiment. Though admittedly biased in favor of Andrew Jackson, Remini (1988a) submits that Jackson was a racist in terms of how he perceived Native Americans, and concedes that the process of removal was abhorrent. He also proclaims, however, Jackson's rationale for removal was not formed through racist views or greed for land, but was instead based on Jackson's belief that he was looking out for the best interest of the Native Americans and American settlers (Remini, 2001). Ever since Jackson was a boy, he was attuned to the hostility and violence that ensued from conflicts between American settlers and Native Americans over land. Also, during Jackson's time fighting British troops during the War for Independence, Jackson observed that Native Americans could ally with foreign aggressors. Native Americans under the influence of foreign powers did not bode well for settlers left vulnerable in the wild frontier (Remini, 2001).

Andrew Jackson hoped that Native Americans would accept treaties offered by the government for their lands and move west of the Mississippi River to continue in their native ways; furthermore, he believed that the process of removal should be voluntary on the part of the Native Americans. If Native Americans did not want to give up their lands, Jackson urged that they become civilized members of society, adhering to the laws and lifestyle of the American public (Remini, 1988a). Remini (2001) does note, 
however, that when things did not go as Jackson hoped, he forced the situation. When acceptance of treaties did not go as planned, Jackson permitted the use of intimidation and bribery to get tribes to sign land treaties (Remini, 2001). In the case of tribes that became "civilized," namely the Cherokees, Jackson forced them to move anyway, regardless of court rulings in their favor (Remini, 1988a). Jackson was determined to strengthen national security, namely the southern frontier, and this involved removing Native Americans west of the Mississippi River. For Jackson, national security issues trumped any rights that belonged to the Native Americas (Remini, 1988a).

A divergent perspective on removal emphasizes what Andrew Jackson had to gain from Native American removal. Jackson's motivation for Native American removal has been distinguished as a desire for lucrative land holdings that would become available to him, as well as purchases of land he could arrange once Native Americans groups ceded these lands through treaties (Wallace, 1993). While acting as commissioner during treaty sessions between Native American groups and the federal government, Jackson approved the use of bribery to persuade Native American chiefs to cede land (Wallace, 1993). Jackson would also influence the government to appoint surveyors of his preference so speculators like him would be in a position to reap the benefits of preferential treatment such as bidding unopposed for a coveted plot of land or shares in a land company (Wallace, 1993).

Historian Michael Paul Rogin viewed Andrew Jackson's motivations for removal through a psychoanalytical lens (as cited in Garrison, 2013). He asserts that experiencing the destruction of his family during a war that involved Native Americans allying with foreign assailants affected Jackson's mentality towards Native Americans (Rogin, 1975). 
He associated Native Americans with his lost childhood (Rogin, 1975). This disposition reemerged during his wars and treaties with Native Americans, as well as Native American removal, as Jackson reverted to his childhood longings (Rogin, 1975). Jackson also regressed to the violent temperament of his adolescence during his encounters with Native Americans as an adult, looking to rid himself of his rage (Rogin, 1975). In regards to the removal of Native Americans, some historians submit to a combination of these theories, though lending more credence to certain perspectives over others.

This is the historical terrain in regards to Andrew Jackson. This represents what historians agree and disagree about regarding Jackson's historical significance. My research explores the areas of convergence and divergence between historians and authors of young adult literature in regards to how the history is written. No trade book intended for young adults can comprehensively address every issue as even historians' products are not comprehensive. It is important, however, to understand what is included, how it is included, and what is left out in a trade book.

\section{Methods}

Rigorous qualitative research methods were used in order to generate a comprehensive, representative, and randomly selected data pool of children's literature (Krippendorff, 2013). A search was performed for published literature intended for the elementary school through middle school grade levels, with Andrew Jackson being the central character of each book. The search for books that are currently in print fitting these criteria yielded 32 books, of which 29 could be obtained. With a data pool that consists of over 90 percent of the available books, the study is close to comprehensive. The list of books that form the data pool can be viewed in Trade Books on Andrew' 
Jackson (Appendix A). Lexile measures in regards to the CCSSI were used to determine the appropriate grade levels of the books.

Rigorous qualitative research methodology was used in order to scrutinize the data pool (Bickford \& Rich, 2014b; Chick \& Corle, 2012; Krippendorff, 2013). The content analysis tool for the initial reading of the books was meant to cast a wide net over Andrew Jackson's life. Broadening the scope of the tool to include Jackson's entire life, through his youth, life on the frontier, military career, and presidency, made it possible to explore and record observations while detecting patterns that emerged in the books.

Notes were recorded during the first reading of the entire data pool, and were reviewed in preparation for revising the content analysis tool to include observable patterns. The entire data pool was then reread using the revised content analysis tool to yield a more focused analysis. The findings that resulted are empirical in that they are observed through reading each book, and quantified in that they are sorted into categories to distinguish trends within the data pool.

Observations from the data pool were classified as either explicit and detailed, explicit but minimized, or implicit/vague. In order for an observation to be classified as explicit and detailed, it had to be explicitly included in two or more sentences in the text of the book, with at least one sentence in the narrative. The other sentence could be in the Foreword or Afterword. An explicit but minimized observation is explicitly included in one but only one sentence; this sentence can be located in either the Foreword, narrative, or Afterword. An implicit/vague observation is implicitly included in the Foreword, narrative, or Afterword. These coding procedures are listed within the content 
analysis protocol that was used for the reading of the data pool, which can be viewed in Content Analysis Tool (Appendix B).

A weakness to be noted in this research is that the data pool was unilaterally analyzed. It is possible that a different observer of the books could indeed detect a pattern portrayed in the books that I overlooked. To mitigate this weakness multiple readings of the data pool were conducted. Through multiple readings, I was able to hone in on patterns that became observable through previous readings as well as make necessary adjustments to questions.

One example of how the content analysis protocol developed is that the content analysis protocol implemented for the first reading of the data pool asked if the author depicted the ideas synonymous with Jacksonian Democracy. The characteristics and definition of Jacksonian Democracy can vary depending on who is asked to define the term, and with the way the question was originally phrased, a set view of Jacksonian Democracy would have had to been distinguished before any patterns could be observed. In the revised content analysis protocol, however, the question asks if the author used the term Jacksonian Democracy, and if so, how did the author define the term. This rephrasing of the questions allowed me to observe the authors' conception of Jacksonian Democracy, and compare their ideas with the perspectives of historians. This discussion about how scrutiny of Jacksonian Democracy evolved is intended to be an illustrative, but not exhaustive, example of the development of the content analysis protocol. Other, similar changes were made. 


\section{Resullts}

It appears that no other empirical study has examined such a high percentage of the data pool. It is also noteworthy that no other empirical study of trade books seems to have examined a data pool that is as heavily dominated by works of historical non-fiction as the criteria for my data pool yielded, as 100 percent of the books collected for this research are historical non-fiction. Findings from the data pool show different viewpoints about Andrew Jackson regarding different aspects of his life and his decisions as the President of the United States. These findings will help guide teachers to develop rich, text-based curricula about Jackson and the events in which he was involved. Illustrative examples of some of the findings are listed in Analysis Results (Table 1).

\section{Book Series and Publication Date}

Most books ( $n=22 ; 76 \%$ ) were from book series with no two books coming from the same series. A reoccurring theme for the book series pertained to the lives of the Presidents of the United States. A majority of the books $(n=18 ; 62 \%)$ were published in or after 1990. In this majority, half of the books were from 1990 to 1999 , with the other half being published in or after 2000 . There were seven books (24\%) published between 1980 and 1989 , and a small portion of the data pool $(n=4 ; 14 \%)$ was published prior to 1980. Andrew Jackson is just as divisive a figure today as he was in his time, but every book in the data pool was written well over a hundred years after his death, offering enough time for historians to have broken down Jackson's legacy, with subsequent generations having the opportunity to put forth their own ideas and rebuttals. Thus the authors of the books are writing with the luxury of a dense historiography to reference. 


\section{Analvsis Results}

1. Stated Jackson owned slaves, had slaves working on his plantation, or saw nothing wrong with slavery:

2. Stated Jackson physically threatened his soldiers, ordered soldiers killed, or had men who helped Native Americans killed.

3. Stated Jackson was for Native American removal because he believed Native Americans did not have any rights to the land they claimed:

4. Stated Jackson believed Native American removal was in the best interest for Native Americans, frontier settlers, or national security:

5. Depicted anti-removal sentiment in the form of legal cases or public opinion:

6. Stated that many Native Americans died during the process of being forcibly removed from their lands:

7. Stated the lands Native Americans claimed were coveted by American settlers because they were fertile farm lands:

8. Stated the financial distress that occurred after Jackson's ending of the Second Bank of the United States:

9. Stated the compromise bill by Henry Clay helped to resolve the Nullification Crisis:

10. Used and defined the term Jacksonian Democracy:

11. Incorporated primary sources:

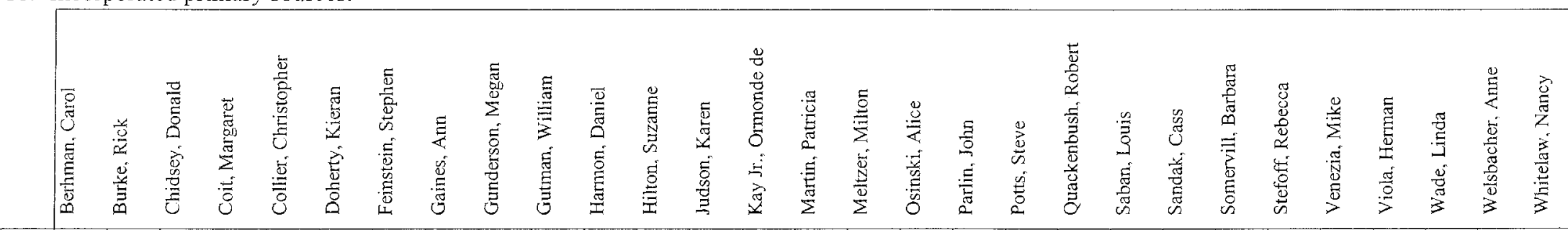

\begin{tabular}{|c|c|c|c|c|c|c|c|c|c|c|c|c|c|c|c|c|c|c|c|c|c|c|c|c|c|c|c|c|}
\hline 1. & $x$ & & $x$ & $x$ & & $x$ & $x$ & $x$ & & $x$ & & $x$ & $x$ & & $x$ & $x$ & & $x$ & & & $x$ & $x$ & $x$ & $x$ & $x$ & $\mathrm{x}$ & $x$ & $x$ \\
\hline 2. & $x$ & & $x$ & $x$ & $x$ & $x$ & & & & $x$ & & $x$ & $x$ & & $x$ & $x$ & $x$ & & & & $x$ & $x$ & $x$ & & $x$ & & $x$ & $x$ \\
\hline 3. & $x$ & & & & & $x$ & & $x$ & & & & & & $x$ & & & & & & & & & & & & & & $x$ \\
\hline 4. & $x$ & $x$ & $x$ & $\mathrm{x}$ & $x$ & $x$ & $x$ & & & $x$ & & $x$ & . & & $\mathrm{x}$ & $x$ & & $x$ & & & $x$ & $x$ & $x$ & $x$ & $x$ & & & $x$ \\
\hline 5. & & & $x$ & $x$ & $x$ & $x$ & $x$ & $x$ & $x$ & & & $x$ & $\mathrm{x}$ & & $x$ & $x$ & $\mathrm{x}$ & 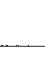 & & $x$ & $x$ & $\mathrm{x}$ & $x$ & $x$ & $x$ & $x$ & & $\mathrm{x}$ \\
\hline 6. & $x$ & $x$ & & $x$ & $x$ & $x$ & $\mathrm{x}$ & $x$ & $x$ & & & $x$ & $x$ & & $x$ & $x$ & $x$ & $x$ & & & $x$ & $x$ & $\mathrm{x}$ & & $\mathrm{x}$ & & & $x$ \\
\hline 7. & & & $x$ & $x$ & $x$ & $x$ & & & & & & 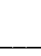 & & & $x$ & & & $x$ & & & . & . & $x$ & & & & & $x$ \\
\hline 8. & & $x$ & & $x$ & $x$ & $x$ & $x$ & & & & & $x$ & & & $x$ & . & $\mathrm{x}$ & & & & $x$ & $\mathrm{x}$ & $x$ & 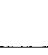 & $x$ & $x$ & & $x$ \\
\hline 9. & & $\mathrm{x}$ & $x$ & $x$ & $x$ & $\mathrm{x}$ & $x$ & & $x$ & & & $x$ & & & $x$ & $\mathrm{x}$ & & & & & & & $x$ & $x$ & $x$ & $x$ & & \\
\hline 10. & $\mathrm{x}$ & 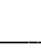 & 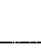 & $x$ & 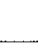 & - & 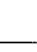 & & $x$ & & & $x$ & & & 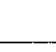 & & & & & & & & $x$ & & $x$ & & & \\
\hline 11. & $\mathrm{x}$ & $\mathrm{x}$ & $x$ & $x$ & $x$ & $\mathrm{x}$ & $x$ & $\mathrm{x}$ & $x$ & $x$ & $x$ & $x$ & $x$ & & $x$ & $x$ & $\mathrm{x}$ & $x$ & $x$ & $x$ & $x$ & $x$ & $x$ & $\mathrm{x}$ & $x$ & & $x$ & $\mathrm{x}$ \\
\hline
\end{tabular}


Sara Schwebel (2011), when examining publication dates of historical fiction books, contended that publication dates should not be overlooked, in that a book can serve as a microcosm in terms of how historians, children's book authors, and the public viewed historical topics at a given moment in time. However, my examination of historical non-fiction about Andrew Jackson does not corroborate Scwhebel's assertion. Publication Date (Table 2) organizes the data pool by decade published, and no significant differences in findings among the decades are palpable. The biggest discrepancies surface in a comparison of books from the $1980 \mathrm{~s}$ and $1990 \mathrm{~s}$ after the books are broken into subgroups in terms of intended grade level, as seen in Publication Date and Intended Grade Level (Table 3). It must be noted that at this point however, no subgroup consists of more than five books. It should also be noted that there were only three books (10\%) written on Jackson from the $1960 \mathrm{~s}$, and only one book (3\%) from the 1970s that fit the requirements for the data pool. More research needs to be done on historical non-fiction books to determine the relationship between the time period they were published and their historical representation (Schwebel, 2011). A historical topic that would elicit a larger data pool of non-fiction books, with a significant number of books from each decade for specific grade levels is recommended. While in this study clear differences among books with different publication dates do not arise from the findings, the same cannot be said when looking at the intended grade level of the books.

\section{Grade Level and Book Genre}

The data pool is almost evenly split between books intended for the intermediate grade levels of $3^{\text {rd }}$ grade to $5^{\text {th }}$ grade, and books intended for the middle grade levels of 


\section{Publication Date}

1. Stated Jackson owned slaves, had slaves working on his plantation, or saw nothing wrong with slavery:

2. Stated Jackson physically threatened his soldiers, ordered soldiers killed, or had men who helped Native Americans killed.

3. Stated Jackson was for Native American removal because he believed Native Americans did not have any rights to the land they claimed:

4. Stated Jackson believed Native American removal was in the best interest for Native Americans, frontier settlers, or national security:

5. Depicted anti-removal sentiment in the form of legal cases or public opinion:

6. Stated that many Native Americans died during the process of being forcibly removed from their lands:

7. Stated the lands Native Americans claimed were coveted by American settlers because they were fertile farm lands:

8. Stated the financial distress that occurred after Jackson's ending of the Second Bank of the United States:

9. Stated the compromise bill by Henry Clay helped to resolve the Nullification Crisis:

10. Used and defined the term Jacksonian Democracy:

11. Incorporated primary sources:

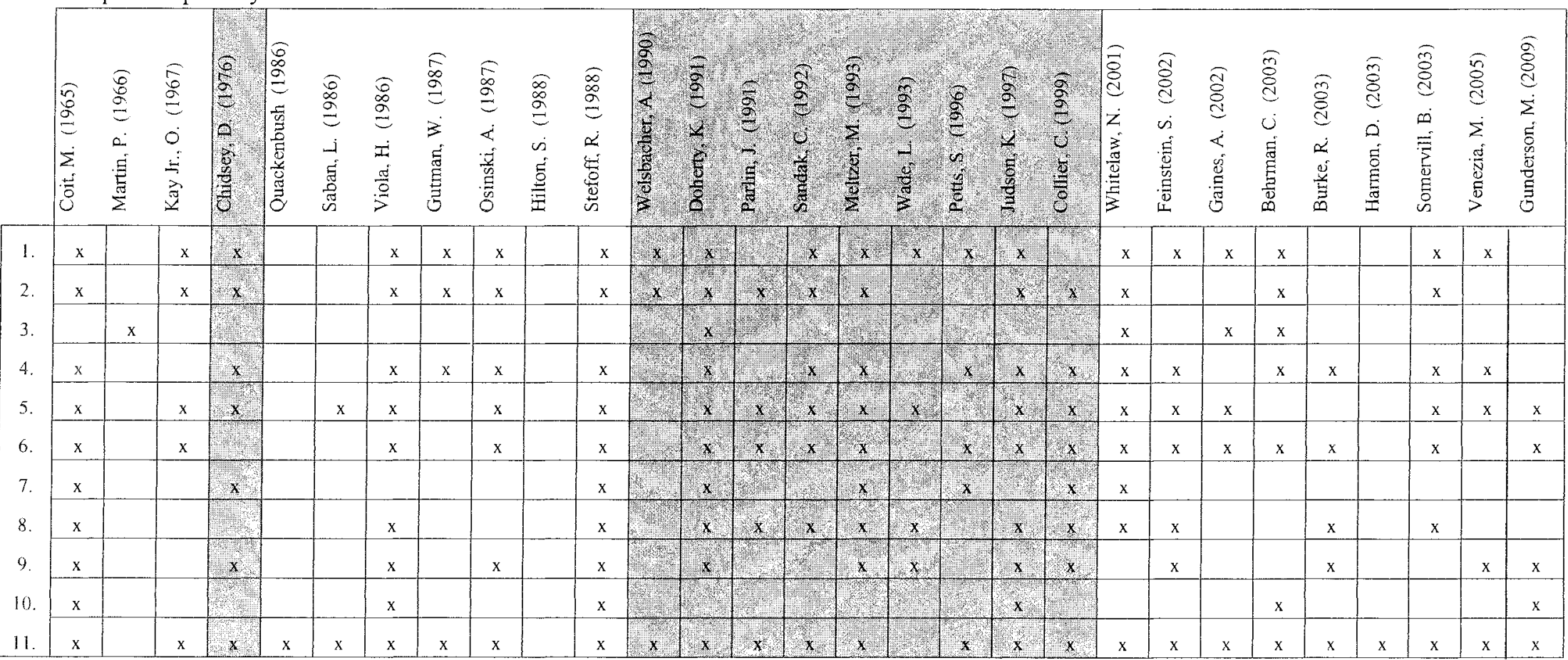


Publication Date and Intended Grade Level

1. Stated Jackson owned slaves, had slaves working on his plantation, or saw nothing wrong with slavery:

2. Stated Jackson physically threatened his soldiers, ordered soldiers killed, or had men who helped Native Americans killed.

3. Stated Jackson was for Native American removal because he believed Native Americans did not have any rights to the land they claimed:

4. Stated Jackson believed Native American removal was in the best interest for Native Americans, frontier settlers, or national security:

5. Depicted anti-removal sentiment in the form of legal cases or public opinion:

6. Stated that many Native Americans died during the process of being forcibly removed from their lands:

7. Stated the lands Native Americans claimed were coveted by American settlers because they were fertile farm lands:

8. Stated the financial distress that occurred after Jackson's ending of the Second Bank of the United States:

9. Stated the compromise bill by Henry Clay helped to resolve the Nullification Crisis:

10. Used and defined the term Jacksonian Democracy:

11. Incorporated primary sources:

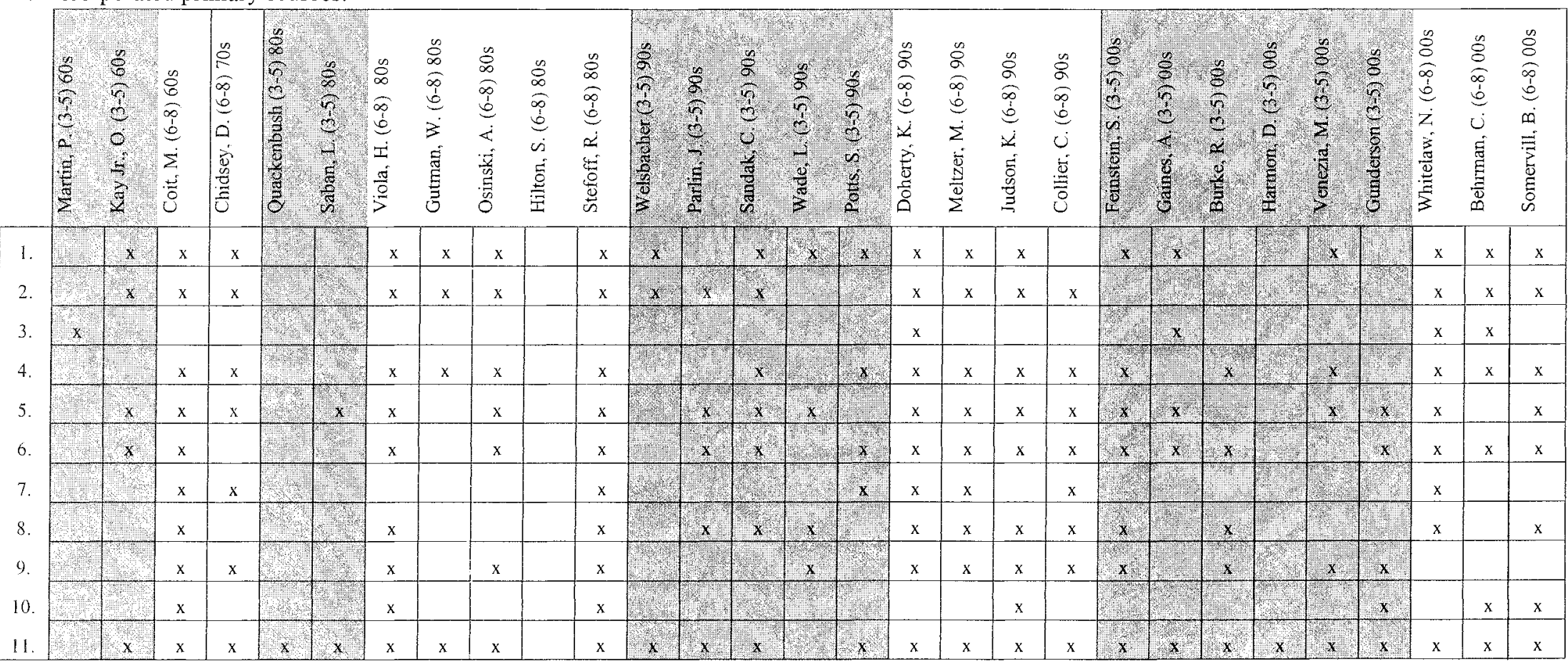


$6^{\text {th }}$ grade to $8^{\text {th }}$ grade, with a slight minority of books $(n=14 ; 48 \%)$ intended for a middle level audience. A virtual split in the data pool in terms of intended grade level can be beneficial for middle school teachers as they will be able to meet the needs of struggling readers by having books that are at their reading levels. All of the books in the data pool fall under the category of historical non-fiction, with biography the overwhelming majority $(n=27 ; 93 \%)$

While there is not enough variety of book genres in the data pool to warrant an indepth comparative analysis, the same is not true for the intended grade level. The split in that data pool pertaining to intended grade level allows for a unique comparison, which can be seen in Intended Grade Level (Table 4). A cursory glance at the table shows that fewer than half of the intermediate grade level books will inform students of how ruthless Andrew Jackson was known to be as a military general, why he advocated for the removal of Native Americans, or why American settlers wanted the lands that Native Americans claimed. The intermediate grade level books are also more likely to exhibit historical misrepresentations. These findings are significant due to the likelihood that classification of a trade book as historical non-fiction will lead students to believe the information in the book is not only true, but also comprehensive (Loewen, 2010; Schwebel, 2011; Wineburg, 2001). The problem is exacerbated considering historical trade books do not go through the rigorous review process that textbooks go through insofar as being scrutinized for historical accuracy (Loewen, 1995; Schwebel, 2011). Findings from this research, therefore, will guide teachers as to what information needs to be supplemented with the narratives of specific trade books that students are 
Intended Grade Level

1. Stated Jackson owned slaves, had slaves working on his plantation, or saw nothing wrong with slavery:

2. Stated Jackson physically threatened his soldiers, ordered soldiers killed, or had men who helped Native Americans killed.

3. Stated Jackson was for Native American removal because he believed Native Americans did not have any rights to the land they claimed:

4. Stated Jackson believed Native American removal was in the best interest for Native Americans, frontier settlers, or national security:

5. Depicted anti-removal sentiment in the form of legal cases or public opinion:

6. Stated that many Native Americans died during the process of being forcibly removed from their lands:

7. Stated the lands Native Americans claimed were coveted by American settlers because they were fertile farm lands:

8. Stated the financial distress that occurred after Jackson's ending of the Second Bank of the United States:

9. Stated the compromise bill by Henty Clay helped to resolve the Nullification Crisis:

10. Used and defined the term Jacksonian Democracy:

11. Incorporated primary sources:

\begin{tabular}{|c|c|c|c|c|c|c|c|c|c|c|c|c|c|c|c|c|c|c|c|c|c|c|c|c|c|c|c|c|}
\hline $\begin{array}{l}\frac{3}{3} \\
\frac{3}{2} \\
\frac{5}{5}\end{array}$ & $\begin{array}{l}n \\
0 \\
5 \\
\frac{6}{3} \\
\frac{3}{6} \\
\frac{3}{6}\end{array}$ & $\begin{array}{l}\hat{n} \\
\hat{3} \\
\frac{6}{8}\end{array}$ & $\frac{0}{i}$ & 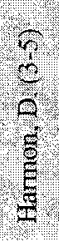 & $\begin{array}{l}\frac{1}{2} \\
0 \\
5 \\
3\end{array}$ & $\begin{array}{l}6 \\
\frac{6}{2} \\
\frac{8}{2}\end{array}$ & $\begin{array}{l}\frac{6}{3} \\
\frac{5}{8} \\
\frac{5}{8}\end{array}$ & $\begin{array}{l}3 \\
3 \\
\frac{3}{3}\end{array}$ & $\frac{a}{\frac{3}{3}}$ & $\begin{array}{l}2 \\
\frac{3}{3} \\
\frac{5}{3}\end{array}$ & $\begin{array}{l}\frac{6}{3} \\
\frac{\pi}{g}\end{array}$ & $\begin{array}{l}\frac{5}{3} \\
\frac{3}{5}\end{array}$ & $\frac{\sigma}{5}$ & $\begin{array}{l}\frac{1}{3} \\
\frac{3}{3} \\
\frac{3}{3} \\
\frac{3}{3}\end{array}$ & 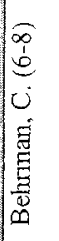 & 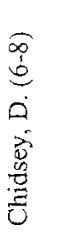 & 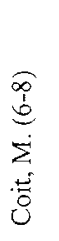 & $\begin{array}{l}\hat{\alpha} \\
\underline{b} \\
\dot{0} \\
\dot{0} \\
\stackrel{\overrightarrow{0}}{0} \\
\dot{0}\end{array}$ & 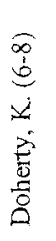 & 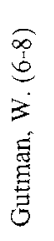 & 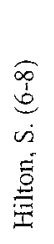 & 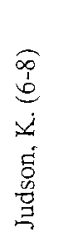 & 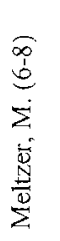 & 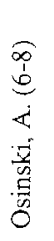 & 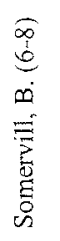 & 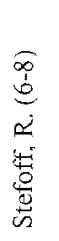 & 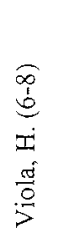 & 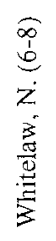 \\
\hline & $x$ & $x$ & & & $x$ & & . & X & E & & $x$ & $x$ & $x$ & $x$ & $x$ & $\mathrm{x}$ & $x$ & & $x$ & $\mathrm{x}$ & & $x$ & $x$ & $x$ & $x$ & $x$ & $x$ & $x$ \\
\hline & & 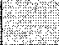 & 3 & & $x$ & & $x$ & $\int$ & 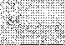 & 政 & $x$ & X & 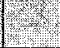 & $x^{2}$ & $x$ & $\mathrm{x}$ & $x$ & $x$ & $x$ & $x$ & & $x$ & $x$ & $x$ & $\mathrm{x}$ & $x$ & $x$ & $x$ \\
\hline & 4 & $\mathrm{x}$ & & & & $\mathrm{x}$ & & & 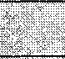 & & & & (1) & & $x$ & & & & $x$ & & & & & & & & & $x$ \\
\hline$x$ & $x$ & $y$ & & & $x$ & & (1) & $x$ & 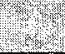 & & $x$ & $\mathrm{x}$ & , & & $\mathrm{x}$ & $x$ & $x$ & $x$ & $x$ & $x$ & & $x$ & $x$ & $x$ & $x$ & $x$ & $x$ & $x$ \\
\hline & $x$ & $x$ & $\int \mathrm{x}$ & & $x$ & & ; x & & 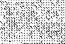 & $\mathrm{x}$ & X & $x$ & $\mathrm{x}$ & & & $x$ & $x$ & $\mathrm{x}$ & $x$ & & & $x$ & $x$ & $x$ & $x$ & $x$ & $x$ & $x$ \\
\hline $\mathrm{x}$ & $x$ & $x$ & $\mathrm{x}$ & & 3 & & $\mathrm{x}$ & $x$ & is & & $x$ & & & & $x$ & & $x$ & $x$ & $x$ & & & $\mathrm{x}$ & $x$ & $\mathrm{x}$ & $x$ & $\mathrm{x}$ & $x$ & $x$ \\
\hline & 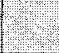 & & (2) & & $1 \%$ & & (W) & $x$ & 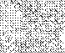 & & & & W & & & $x$ & $x$ & $x$ & $x$ & & & & $x$ & & & $x$ & & $x$ \\
\hline$x$ & X & & 8 & & X & the & $\mathrm{x}$ & 2 & 4 & & X & 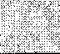 & $x$ & & & & $x$ & $x$ & $x$ & & & $x$ & $x$ & & $x$ & $x$ & $x$ & $\mathrm{x}$ \\
\hline $\mathrm{x}$ & $\times$ & & $x$ & & & & & & & & & $x$ & x & & & $x$ & $x$ & $x$ & $x$ & & & $x$ & $x$ & $x$ & & $x$ & $\mathrm{x}$ & \\
\hline & W & 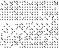 & $\mathrm{x}$ & W & & & & 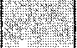 & & & W & & S & (2) & $\mathrm{x}$ & & $x$ & & & & & $x$ & & & & $x$ & $\mathrm{x}$ & \\
\hline $\mathrm{x}$ & $x$ & $x$ & x & $\sqrt{x}$ & $x$ & & & $x^{2}$ & $x^{2}$ & $x$ & $x$ & $1 \times$ & Ut) & $1 \times$ & $x$ & $x$ & $x$ & $x$ & $x$ & $x$ & & $\mathrm{x}$ & $x$ & $x$ & $x$ & $x$ & $x$ & $\mathrm{x}$ \\
\hline
\end{tabular}


reading. Primary sources can represent the information and perspectives not covered by trade books and textbooks.

\section{Primary Sources}

Almost all of the data pool $(n=27 ; 93 \%)$ incorporated primary sources in at least one manner. The primary sources incorporated by books took the form of quotes from Andrew Jackson or about him, various political cartoons depicting President Jackson, paintings of Jackson or people involved in Jackson's life, and artifacts such as advertisements, documents, and Jackson memorabilia.

Though an overwhelming majority of the books from the data pool are classified as historical non-fiction, and additionally incorporated primary sources, historical misrepresentations still surfaced within the data pool. When it comes to scrutinizing these primary sources students should be considering whether the author considered all the possible primary sources available before deciding on the sources that enhance the historical authenticity of the book, chose sources that convey a biased perspective, or simply chose sources that enhance the book's narrative. In reality, just as students are likely to trust a trade book's narrative, they are also likely to trust all the content that lies within the book itself, not excluding primary sources (Loewen, 2010; Wineburg, 2001). This affirms that educators need to supplement the reading of the trade books from the data pool with primary sources that provide a more nuanced narrative. Educators, consequently, are able to use the primary resources in the discussion section to promote a more complete historical account of Andrew Jackson.

\section{Time Frames of Jackson's Life}


Most of the books $(n=27 ; 93 \%)$ from the data pool touched upon five distinct time periods of Andrew Jackson's life. First, every book depicted Jackson's upbringing. This depiction usually involved stating Jackson's humble origins, his involvement in the American Revolution, and the fact that his entire family had died by the time he was around 15 years old. Second, all but one book presented aspects of Jackson's time on the frontier west of the Appalachian Mountains, typically including Jackson's stints as a lawyer and judge, his marriage to Rachel Donelson and subsequent building of their plantation, and conflicts over land with Native Americans. Third, with the exception of one book the entire data pool followed Jackson's life while he was in the military. Here the books describe Jackson's relationships with his soldiers, his battle against Native Americans tribes such as the Creeks and Seminoles, and his triumph against the British in the Battle of New Orleans during the War of 1812.

Fourth, all but one book mentioned various aspects of Andrew Jackson's time as President of the United States. Highlights during this section of the books often included his devotion to the people he believed were not being represented by the government, and his involvement in the forced removal of Native Americans, the Nullification Crisis, and the battle with the Second Bank of the United States. Finally, all but two of the books from the data pool depicted his life after his retirement from political life, often including Jackson returning to his plantation.

The significance of these time periods are confirmed as works of historians cover these aspects of Andrew Jackson's life as well. Jackson's humble upbringing as well as his patriotism as a boy during the American Revolution made him an identifiable figure to those who would elect and re-elect him as President (Murphy, 2013). His time on the 
frontier would forge the beliefs that would guide him in his decisions as President concerning Native Americans and the Second Bank of the United States (Meacham, 2008). His actions in the military would solidify his reputation to many as a war hero that was apt to make rash decisions unilaterally (Meacham, 2008), and his time as President redefined the role of the Presidency in terms of power the office held and its relationship to American citizens (Remini, 1967).

\section{Jacksom's Views on Slavery}

From the perspective of historians, with 500,000 slaves in the thirteen colonies when Andrew Jackson was born and 2,500,000 slaves in the U.S. when he died, slavery was an institution that was thriving in the U.S., especially in the South, where cotton fields were spreading rapidly (Gudmestad, 2013). Though Jackson and the Democratic Party tried to make slavery a non-issue (Remini, 1988a), through the Nullification Crisis Jackson recognized the issue was going to emerge in regards to disunion (Meacham, 2008). By the 1830s, the abolitionist movement was more predominant yet unsettled about how to best end slavery and what role African Americans would assume after slavery ended (Gudmestad, 2013).

Over half of the books ( $n=17 ; 58 \%$ ) from the data pool stated Andrew Jackson's views on slavery by explicitly stating that Jackson owned slaves, had slaves working on his plantation, or saw nothing wrong with slavery. For example, in Carol Behrman's (2003) Andrew Jackson, which I have categorized as a middle level book, when speaking of Jackson, his wife, and their plantation, the text stated, "...they owned slaves to work the fields. Many Americans believed that slavery was immoral, but Jackson and most other Southemers saw nothing wrong with it" (p. 39). A small portion ( $n=3 ; 10 \%)$ of 
the books offered only a vague depiction of what stance Jackson had toward the issue of slavery. Mike Venezia”s (2005) Andrew Jackson: Seventh President stated, "Because a lot of people [Jackson] helped didn't have money, [Jackson] was often paid in cotton, whiskey, slaves, land, or farm animals" (p. 16).

Students should be aware of the fact that historians confirm Andrew Jackson was a slaveholder, and viewed slaves as property protected by the U.S Constitution (Remini, 1988a), for the issue of slavery would continue to gain momentum beyond the time of Jackson's Presidency into the Civil War. References to slavery during Jackson's time help students comprehend that it did not just become an issue over the course of a few years that quickly led to a civil war, but was a main topic of debate for abolitionists decades before the Civil War commenced, and was an underlying issue for the country decades before Jackson's Presidency (Wilentz, 2005). Having this awareness will help students to make a fair judgment about Jackson's character and contextualize how people of the era viewed the issue of slavery. It is also important to note though Jackson usually treated his slaves decently by the standards of the time, he was not hesitant to have his slaves whipped or chained (Remini, 1988b). This is stated in Milton Meltzer's Andrew Jackson and His America and Nancy Whitelaw's Andrew Jackson: Frontier President, both from the data pool.

Of the books from the data pool intended for intermediate grade levels that included his views on slavery, none depicted any inhumane treatment of slaves that might be deemed inappropriate for students at this level; however, two books stated that Jackson treated his slaves well or humanely. Though it is understandable an author attempting to keep a narrative appropriate to an intended grade level might not inciude 
Jackson's occasional inhumane treatment of his slaves, it is a historical misrepresentation, regardless of the grade level of an intended reader, to state Jackson treated his slaves "humanely" when historians' views confirm that he at times did otherwise.

Teachers of intermediate grades should use their own discretion on whether to go into this much detail in regards to Andrew Jackson's treatment of his slaves. It is important to note, however, that struggling middle school readers are likely to read intermediate level books. With an intermediate book as the sole resource, they are less likely to read about Jackson's views on slavery, or other more controversial aspects of Jackson's life. At the middle school level, students should be introduced to these perspectives about Jackson to form a more complete historical understanding of him, and the implementation of primary sources to supplement an intermediate grade level book is recommended in the case of struggling middle schools readers. The primary sources in the discussion section give insight into Jackson's treatment of his slaves and his view about the issue of slavery.

\section{Depicting Violence in the Military}

Historians confirm during his military career Andrew Jackson threatened to shoot his own soldiers if they deserted his army, quelled what he thought to be a mutiny by ordering the execution of one of his own men, and had two British men killed for aiding Native Americans in Florida. These actions and decisions would be used against Jackson by his political enemies when he ran for the Presidency in 1828, and confirmed for many that Jackson could be a ruthless killer (Remini, 1988b).

A small majority $(n=17 ; 59 \%)$ of books from the data pool mentioned that Andrew Jackson would resort to violence in order to do what he felt was necessary to 
keep his soldiers in line and his army intact. Some books stated Jackson threatened to shoot his own soldiers that threatened desertion, as in Margaret Coit's (1965) Andrew Jackson, when the text stated, "Jackson galloped ahead, ordered General Coffee to fire on any deserter..." (p. 42). In Andrew Jackson, by Karen Judson (1997), the text emphasizes Jackson's mercilessness by describing a situation in which a young soldier was caught away from his post, stating "Jackson made an example of him by ordering his court-martial and execution" (p. 51). This indicates that Jackson would go to extremes to do what he felt was in the best interest of his militia.

There are also examples that showed Andrew Jackson was just as cruel to civilians that he felt were harming his army's ability to complete orders. An account describing Jackson dealing with two British men accused of aiding Native Americans can be read in Alice Osinski's (1987) Andrew Jackson, where the text stated, "Jackson had found two British citizens who had been encouraging Seminoles to fight the Americans. He had them killed" (p. 55). These actions affirm how cruel and merciless Jackson was to those he felt to be enemies.

The question arises of whether depicting Andrew Jackson's willingness to have his own men and civilians put to death in order to carry out his objectives is appropriate for students at the intermediate grade levels. I argue that it is pertinent information for students to know in order for them to fully understand what Jackson believed was in the best interest of his army and the country, as long as the narrative does not depict the events in gruesome detail. In all the books that depicted violence, none of them in my opinion went into enough detail that reading about it would be too upsetting for students or would make for an adverse learning experience. For teachers looking to incorporate 
his brashness as a military general, the primary sources in the discussion section will help.

\section{Native Americans}

Andrew Jackson's involvement with Native Americans was a reoccurring theme through his life as depicted by historians. Land conflicts kept the frontier settlements where Jackson resided on guard from attacks by Native Americans trying to keep settlers from settling on the land they claimed (Remini, 1988b). He fought wars against tribes over land, and later was in charge of making treaties with tribes in regards to the exchange of land (Remini, 2001), and one of his first acts of legislature as President was to sign into law the requirement that Native Americans move west of the Mississippi River (Meacham, 2008).

Every book in the data pool mentioned Native Americans in one capacity or another. A large majority $(n=25 ; 86 \%)$ of the books referred to the population as Indians, almost a third $(n=10 ; 34 \%)$ of the books referred to the population as Native Americans, and a few $(n=5 ; 17 \%)$ books referred to the population as American Indians. All the books from the 1960s, 1970s, and 1980s referred to the population as Indians, American Indians, or both. A trend in authors referring to the population as Native Americans is seen in some of the books $(n=10 ; 34 \%)$ from the $1990 \mathrm{~s}$ and $2000 \mathrm{~s}$, which indicates the evolving nature of identification terms for this group of people.

The way Native Americans were portrayed in the data pool included minimalizing the presence of the people by stating only that Andrew Jackson's hometown settlement was free of the fear of possible raids by Native Americans when he was a child $n=1$; $3 \%$, to the explicit and detailed depiction of the forced removal of Native Americans 
from their lands during Jackson's Presidency $(n=15 ; 52 \%)$. Specifically in regards to Jackson's time in the military, many books depicted Jackson's battles against the Creek or Seminole tribes $(n=25 ; 86 \%)$, and a few books $(n=3 ; 10 \%)$ also mentioned the treaties that Jackson was involved with concerning Native American lands. As the topic of Andrew Jackson's involvement with Native Americans can be a crux for judgment about Jackson (Meacham, 2008; Remini, 1988a), key findings about the portrayal of Native Americans in the data pool are touched upon in subsequent sections of the findings.

Native Americans have been a historically misrepresented group in the past (Loewen, 1995). Through the use of trade books and primary sources, teachers have the opportunity to give students at any grade level a nuanced understanding of Native Americans from multiple perspectives. This is even more important considering Andrew Jackson was the central character of all the books in the data pool with the exception of Andrew Jackson's America: $1824-1850$ by Christopher Collier and James Lincoln Collier, in which Native American groups anchored storylines within the narrative. The primary sources in the discussion section suggest how Native Americans can be presented to students when minimalized or misrepresented in textbooks or trade books.

\section{A Different Kind of President}

Historians agree that, unlike previous Presidents, Andrew Jackson came from humble origins with both parents being immigrants, and that many people perceived him to be an uncouth backwoodsman (Remini, 1988b). Though his beliefs and actions led some people to declare him a hero looking out for the best interest of the Union, others 
saw him as a tyrant whose controversial decisions did not reflect the country's position as a whole (Warshauer, 2013).

A large majority $(n=25 ; 86 \%)$ of the books from the data pool stated that Andrew Jackson was a unique President compared to the previous six Presidents who served before him, whether referring to his upbringing or personality. A common theme emphasized through almost the entire data pool $(n=28 ; 97 \%)$ was Jackson's temper. In The World of Young Andrew Jackson by Suzanne Hilton (1988), his temper and its effects are explained:

The one thing Andrew could not tolerate was to be made fun of. When a boy laughed at him, he began to drool. If Andy tried to shout ugly names or holler down his opponent, his mouth filled with saliva and the drool ran down his chin.

Then he became as furious as an enraged bull. (p. 24)

The Washington establishment was worried about what might happen to the country if Jackson was indeed elected to serve as President. For example, in Kieran Doherty's (2003) Andrew Jackson the text stated, "[Jackson's] reputation as a fierce warrior with a hot temper worried many political leaders. What would happen if a backwoodsman like Jackson should become president? they asked" (p. 46).

Historian Jon Meacham (2008) confirms these descriptions of Andrew Jackson, but stated that Jackson's temperament made him suitable for the needs of the White House in a time when there were many arguments about the balance of power between the states and the central government. In his account, Jackson was not a tyrannical bully but a patriot that was able to make clear judgments with the interest of the public in mind (Meacham, 2008). Teachers can lead discussions about Jackson's personality and how 
trade books might emphasize certain aspects of a character's personality to create an engaging narrative. The primary sources listed in the discussion section give insight into Jackson's personality.

\section{Jacksonian Democracy}

Only a fifth $(n=6 ; 21 \%)$ of the authors of books from the data pool used and defined the term Jacksonian Democracy. Behrman's (2003) Andrew Jackson defines the term as "supporting the interests of farmers and small-business owners, laborers, and struggling pioneers" (p. 103). Coit's (1965) Andrew Jackson defines the term as "one man was as fit as another to hold public office" (p. 91). In Andrew Jackson, by Megan Gunderson (2009), the term is related to Andrew Jackson and his supporters vowing to fight for the American people, whose voices had not been heard. In Andrew Jackson, by Judson (1997), Jacksonian Democracy is defined as Jackson's political beliefs. This set of beliefs included appealing to "farmers laborers, and frontiersmen," (p. 93) while being "against the national bank, high taxes on imported goods, and spending federal money for national improvements" (p. 93).

Rebecca Stefoff's (1988) Andrew Jackson: 7th President of the United States defined the term as "emphasis on the importance of the individual American, rather than on established parties or families, in shaping the destiny of the nation" (p. 64). In Andrew Jackson, by Herman Viola (1986), the term is defined by a Franklin D. Roosevelt quote, "that dictates itself to the end that the American people shall...remain the custodians of their own destiny" (p. 103).

Though the idea of Jacksonian Democracy has been connected with suffrage and more citizens having the opportunity to work in government positions (Sacher, 2013), 
historians confirm that the democratization of the U.S. was in process before Andrew Jackson became a political figure (Hofstadter, 1948; Sacher, 2013; Wilentz, 2005). The significance with this term is that the idea of democracy had taken the place of republicanism in the American lexicon by the time Andrew Jackson's time as President came to a close (Remini, 1988a), and the idea of the majority having the right to rule was pervasive in Jackson's mindset (Meacham, 2008; Remini, 1988a). Students should be made aware of the democratic transformation the nation was going through, regardless of how much credit Jackson deserves for the change. The primary sources in the discussion section will help teachers looking to start a discussion about the idea of Jacksonian Democracy. Jackson's intention of letting the majority govern, however, did not include all groups of people.

\section{The Common Man}

Historians confirm that from early in the $19^{\text {th }}$ century up to the elections of 1824 and 1828 , more white male citizens were taking part in the democratic process. Caucusing was losing favor to public meetings and delegate conventions (Coens, 2013), and owning land was no longer a voting requirement (Meacham, 2008; Zakim, 2013). There is general agreement that Andrew Jackson's appeal to the common man helped him in his campaign for the Presidency in 1828 (Murphy, 2013).

The terms common man and/or common people were seen throughout many of the books in the data pool $(n=20 ; 69 \%)$. Eight of the books in this subset made an attempt to define the term or contextualize the term within the time frames the book covered. Viola's (1986) Andrew Jackson defined common man as being "neither aristocratic nor an easterner" (p.65). In Andrew Jackson: $7^{\text {th }}$ President of the United States, by Stefoff 
(1988), "farmers, urban factory and office workers, shopowners, and small businessmen" (p.64) are common people.

Osinski’s (1987) Andrew Jackson contextualizes common people by pointing out that western states were allowing all white males to vote in 1828 whether they owned property or not, and Andrew Jackson received his greatest support from these people, who are referred to as the common people. In this book, when the text stated that Jackson is trying to keep the interests of the common people in mind when making decisions about laws and legisiation, the term connotes that Jackson is looking out for the best interest of white males.

Using the terms common man or common people can become problematic when the terms are not defined or contextualized within the time period being referenced. It is possible that whenever a text mentions the common man or common people being able to vote or take part in the U.S. government, or the fact that Andrew Jackson is looking out for these people, students might construe these terms as inclusive to African-Americans, women, or Native Americans. This can result in students inferring, mistakenly, that Jackson was a reformer for these groups. During Jackson's time, while democracy was indeed expanding for white males, minority groups such as women, African-Americans, and Native Americans were not part of the process (Cole, 2009). These groups never even crossed Jackson's mind in terms of liberty for "all" (Remini, 1988a). The primary sources in the discussion section will help teachers discuss with students how to define terms in context of the time period.

\section{Rationale for Notable Events}


Andrew Jackson was involved in significant events in U.S. history. How authors depict Jackson's rationale for important decisions is likely to affect how students understand Jackson and the event with which he is involved. Four notable events are Jackson`s invasion of Florida (Meacham, 2008), Native American removal (Garrison, 2013; Remini, 2001, Remini, 1988a; Wallace, 1993), the Nullification Crisis (Meacham, 2008, Remini, 1988b), and the battle with the Second Bank of the United States (Meacham, 2008; Remini, 1967).

Invading Florida. Historians note runaway slaves often sought shelter in Spanish-owned Florida (Loewen 1995; Meacham, 2008), and there was also unrest between American settlers and Seminole Native Americans along the George-Florida border (Meacham, 2008). Andrew Jackson believed that possessing Florida and then removing Native Americans from the land would strengthen national security. When Jackson received ambiguous orders from James Monroe to confront the unrest, he took advantage of the ambiguity and invaded Florida (Meacham, 2008).

A majority of the books $(n=18 ; 62 \%)$ from the data pool gave an account of why Andrew Jackson invaded Florida, which belonged to Spain. An appetite for land is given as Jackson's reason for invading in five of the books. In Andrew Jackson: Frontier President, by Whitelaw (2001), the text stated Jackson's goals were to, "Eliminate the Spanish from the southern frontier, eliminate the Native Americans from Florida, and construct a road for westward expansion" (p. 34). In a different group of five books, the texts stated that the invasion was Jackson's decision to retaliate against Native Americans for crossing over into Georgia and attacking Americans settlers and his soldiers, and to preempt any future raids. This can be observed in Ann Graham Gaines's (2002) Andrew 
Jackson: Our Seventh President, as the text stated, "After Native Americans killed some of his troops, Jackson was angry. He did not wait for government orders to tell him what to do. Instead, he and his men marched into Florida" (p. 19).

Six of the books $(21 \%)$ from the data pool, on the other hand, stated that Andrew Jackson was acting on orders given to him by the U.S. government to deal with unrest along the border between Georgia and Florida. For example, Stephen Feinstein's (2002) Andrew Jackson stated, "[James Monroe] wrote to Jackson, asking him to correct the situation. Jackson, assuming Monroe was authorizing an invasion of Spanish Florida, proceeded to launch one" (p. 28). Two of the books stated that Jackson believed the invasion and subsequent seizing of Florida would strengthen the Southern frontier, making the United States more secure. For example, Meltzer's (1993) Andrew Jackson and His America stated, "Jackson's first military goal was to protect the Southern frontier by routing the Spanish out of Florida" (p. 70$)$.

The public actively debated Andrew Jackson's invasion of Florida. The portion of the public that sided with Jackson backed a man they perceived to be defending the safety of the nation and adhering to government orders, whereas his critics were unsettled by what they saw as hawkish unilateral actions without government approval (Warshauer, 2013). When students are considering Jackson's leadership, these divergent historical perspectives on his actions in regards to Florida should be presented for students to discuss.

Native American Removal. In Andrew Jackson's view of the future of the U.S., Native Americans were not present, and he did not waste time debating removal (Meacham, 2008). Jackson did not trust Native Americans and thought they needed to be 
treated like children by someone who knew what was in their best interest (Remini, 2001). The removal of Native Americans to the west of the Mississippi River consumed him during his Presidency (Remini, 1988a).

Over two-thirds $(n=20 ; 69 \%)$ of the books in the data pool mentioned Andrew Jackson's rationale for forcibly removing the Native Americans to the west of the Mississippi River. A subset of the books $(n=5 ; 17 \%)$ stated that Jackson believed the Native Americans did not have any rights to the lands they claimed. Patricia Martin's (1966) Andrew Jackson stated, "Andrew Jackson believed that Indians had no right to land that frontiersmen wanted" (p. 42), and Berhman's (2003) Andrew Jackson stated, "Jackson viewed the Native Americans as savages. He did not believe that they had any rights of ownership over the lands on which they lived" (p. 63).

The rest of the books ( $n=15 ; 52 \%$ ) that mentioned Andrew Jackson's rationale for removal asserted that removal was believed to be in the best interest of the Native Americans themselves, American settlers, or national security. Osinski's (1987) Andrew Jackson puts forth, "Jackson honestly believed that it would be best to move all the Indians west of the Mississippi River to an area that the government would provide for them" (p. 66). In Andrew Jackson, by Barbara Somervill (2003), the text stated, "Many Americans wanted the Indian Removal Act passed, and Jackson gave them what they wanted" (p. 37). One more example is in Cass Sandak's (1992) The Jacksons: "[Jackson] went along with relocation, because he believed that the majority of the American people thought it was right. He also justified this stand by arguing that it was what the Indians themselves wanted" (p. 34). 
The process of forcibly removing Native Americans from their lands is one topic that teachers should let students study from many different perspectives, for it was a poorly executed process that led to the demise of many people (Remini, 1988a). Through the implementation of multiple divergent views about removal, teachers can help students detect bias and form a well-rounded stance on the topic. The primary sources from the discussion section can be utilized by educators to present the topic of removal from the perspectives of different groups of people that lived during the time.

Nullification Crisis. In the Nullification Crisis, historians depict Andrew Jackson in the middle of a sectional conflict that involved states' rights against a strong central govermment. Whereas South Carolinians advocated for states' rights over a federal government they saw as overreaching, Andrew Jackson was steadfast in his defense of the Union, and was willing to wage war against secession (Gannon, 2013). He proclaimed that the Constitution did not give states the right to nullify federal laws, and that disunion was an act of treason (Meacham, 2008).

Nearly three-quarters $(n=22 ; 76 \%)$ of the data pool depicted Andrew Jackson's rationale for not wanting South Carolina to secede from the Union. In almost half the books ( $n=14 ; 48 \%)$, Jackson's rationale is his belief in a strong central government or the notion that if one state seceded, the country could begin to break apart. In Ormonde de Kay, Jr.'s (1967) Meet Andrew Jackson, the text offers an explanation of what would happen if South Carolina seceded by stating, "if the states did that, each would be like a little country. They would no longer be united. Their union would break up. [Jackson] knew he must answer Calhoun" (p. 73). Also, a portion of the books $(n=11 ; 38 \%)$ stated Jackson believed the states did not have the right to secede from the Union or disobey 
federal laws. This is clear in Doherty's (2003) Andrew Jackson, as the text stated, "Jackson issued a stern statement declaring nullification illegal and warning South Carolina that its action might lead to war" (p. 61).

Meltzer (1993), Stefoff (1988), Donald Chidsey (1976), and Collier and Collier (1999) stated in their books that the issue of nullification had implications for the issue of slavery. In Andrew Jackson's America: 1824-1850, by Collier and Collier (1999), the text stated, "If the federal government could shove a protective tariff down southern throats, might it not also interfere with slavery?" (p. 68). In Stefoff"s (1988) Andrew Jackson: $7^{\text {th }}$ President of the United States, the text stated, "Many southerners feared that a strong federal government could threaten their slave-holding rights" (p. 79). These findings confirm the multiple stances historians take on the topic of nullification.

Teachers can discuss with students Andrew Jackson's views on the rights of states and the federal government and how even though he advocated for state's rights regarding internal improvements (Remini, 1988b), he was devoted to the Union and having a strong central government (Meacham, 2008; Remini, 1988b). A primary source in the discussion section gives Jackson's view of nullification and foreshadows its connection to the issue of slavery.

Bank War. Andrew Jackson had many grievances with the Second Bank of the United States. According to Stephen Mihm (2013), Jackson claimed the bank "was unconstitutional, deeply corrupt, a dangerous monopoly, a treacherous servant of foreign governments, and a bastion of aristocratic privilege that threatened the liberties of the farmers, mechanics, and working men who elected Jackson president" (p. 348). Through his own financial distress due to debts, Jackson was very skeptical about banks and bank 
notes (Meacham, 2008), and was instead in favor of using gold and silver as money (Mihm, 2013).

In regards to his actions in office, almost half $(n=15 ; 52 \%)$ of the books mentioned that Andrew Jackson used the veto more than all the previous Presidents combined, or used the veto merely when his disagreed with Congress. One example is his veto of a new charter of the Second Bank of the United States. Nearly three-quarters $(n=22 ; 76 \%)$ of the data pool depicted Jackson's opposition to the bank. In these books, Jackson's reasons for wanting to end the bank included his belief that small banks would be better $(n=5 ; 17 \%)$, his distrust of paper currency $(n=2 ; 7 \%)$, his opinion the national bank was corrupt and too much involved in politics $(n=7 ; 24 \%)$, or that the bank benefited the rich at the expense of the poor $(n=14 ; 48 \%)$.

Andrew Jackson's veto of the new charter of the bank as well as his use of the veto in general needs to be in the minds of students. Jackson always thought about the interest of the American public, or what he deemed to be in the public's best interest, and made decisions accordingly, with the veto of the Second Bank of the United States, whether beneficial or detrimental to the Union, serving as a prime example (Cole, 2009; Meacham, 2008; Remini, 1988a). The primary sources from the discussion section depict Jackson's rationale for ending the bank, and how the public viewed the bank conflict.

\section{Presence of Common Historical Misrepresentations}

Historical misrepresentations are key findings in that they can result in students forming an incomplete or inaccurate understanding of Andrew Jackson, the events in which he was involved, and the people he interacted with. Heroification and omission 
are two common forms of historical misrepresentations that were evident in the books from the data pool. Heroification results when a single figure is given credit for efforts and accomplishments that can also be attributed to other figures (Bickford, 2013a; Loewen, 1995). Omission results when information that contributes to the historical accuracy of a topic is not included in a historical account (Bickford, 2013a).

Heroification. A little over half $(n=15 ; 52 \%)$ of the books from the data pool exhibited heroification. These instances emerged when the text depicted the resolving of the Nullification Crisis, where research found that in some instances, Andrew Jackson was given all the credit for resolving the issue. In Martin's (1966) Andrew Jackson the text stated, "The President made a Proclamation. In this Proclamation, he said that no state had a right to withdrawal from the Union. South Carolina accepted the laws of the Federal Government, and did not withdraw from the Union" (p. 60). Another example is in The Jacksons, by Sandak (1992), as the text stated, "Jackson drew up a proclamation asking the state to reconsider. The state leaders did, and the country was held together-at least temporarily-for another 30 years" (p. 32). Also, in Gaines's (2002) Andrew Jackson: Our Seventh President the text stated, "Jackson threatened to send troops to South Carolina to make its citizens obey the law. Calhoun finally backed down. Jackson then worked to lower the tariff' (p. 32).

Historians note though Andrew Jackson was a prominent figure during the crisis, a compromise bill put forth by Henry Clay contributed significantly to keeping South Carolina from attempting to secede from the Union (Meacham, 2008). The failure to mention the compromise bill contributes to the heroification of Jackson during the crisis. This instance of heroification is avoided in Gunderson's (2009) Andrew Jackson from the 
data pool, as the text stated, "Henry Clay proposed two bills as a solution. The first one lowered the tariff. The second was the Force Bill. It allowed the president to use the military to enforce national laws. Clay's bill helped keep the nation united" (p. 25). Jackson may have been the first to make an overture towards the nullifiers in terms of tariff reform; however, to not state Clay's contribution to the resolving of the crisis would be an injustice, as Clay's compromise is deemed by historians, along with Clay's enemies during his time, as a timely piece of legislature (Meacham, 2008). Analysis Results (Table 1) shows statistics on this finding.

Omission. To further clarify what is deemed an omission, consider Andrew Jackson and his stance on slavery. Not every author of trade books about Jackson will deem his views of slavery appropriate to include in a narrative. An author's choice to avoid the topic of slavery itself is not considered an omission. When an author does however include aspects of Jackson's life that revolve around slavery without mentioning his views or actions, notation of an omission is warranted. It should be noted that some books from the data pool are not checked in the tables, not because they have omitted information, but for the fact that the books did not cover the topic at hand. For example, Hilton's (1988) The World of Young Andrew Jackson only covered Jackson's youth, and therefore did not depict any events that occurred after his youth.

The research reports omissions in a large majority $(n=25 ; 86 \%)$ of the books from the data pool. Omission occurred in four books in regards to Andrew Jackson's stance on slavery, particularly the fact that Jackson owned slaves the worked on his plantation. The works of Gunderson (2009), Martin (1966), John Parlin (1991), and Robert Quackenbush (1986) all mentioned that Jackson had a plantation that he and his 
wife Rachel worked on, but omitted the fact that many slaves contributed unpaid labor. This omission can lead to students attributing the success of the plantation to hard labor being done solely by Jackson and his wife.

In regards to the conflict between American settlers and Native Americans over land, only eight books (Table 1) from the data pool explicitly mentioned that the land in conflict was valuable for farming. This is important, for students might not understand why American settlers did not just bypass the lands that Native Americans lay claim to, and settle west of the Mississippi River to farm lands, since the government had recently acquired vast amounts of land through the Louisiana Purchase.

Failure to state negative sentiment from the public or legal cases against the forced removal of Native Americans from their lands while Andrew Jackson was in office is seen in books from the data pool by Berhman (2003), Rick Burke (2003), William Gutman (1987), Steve Potts (1996), and Anne Welsbacher (1990). When antiremoval sentiment is not included, students reading the books can come away with the understanding that the entire American public was not only in favor of removal, but that no one at the time saw anything wrong with removal.

Books by Gunderson (2009), Linda Wade (1993), and Welsbacher (1990) do not explicitly state why Andrew Jackson thought Native Americans needed to be removed. Students reading these books are left to make assumptions about Jackson's rationale. Also, the texts offered by Chidsey (1976), Gutman (1987), Venezia (2005), Wade (1993), and Welsbacher (1990) omitted the fact that thousands of Native Americans died during removal. This omission has major implications for students' understanding of removal. 
Students reading these books might not grasp how detrimental removal was for Native Americans, for these texts only bring awareness to the loss of land and not the loss life.

The fallout from the ending of the Second Bank of the United States, namely the financial stress that affected the nation, is mentioned in only about half of the books (Table 1). Whether the extent of the financial stress was directly caused by Andrew Jackson's decisions can be debated, but the result should be presented to give students a more complete historical understanding of how Jackson's decisions affected the United States. A compromise bill by Henry Clay that contributed to the resolving of the Nullification Crisis is mentioned in only about half of the books as well. This omission's ramifications manifested in the aforementioned heroification. The primary sources in the discussion section can help fill the gaps of information that were omitted in the books from the data pool.

\section{Discussion}

Findings from the data pool are not meant to be regarded as evaluations of the quality of any certain book, nor are the findings meant to recommend one book from the data pool over another book. Some of the authors might have consciously chosen to not include certain people, events, or topics in order to construct a certain narrative or theme. Other authors, however, at the expense of an engaging narrative, might have made a conscious attempt to keep the narrative historically authentic. To clarify, the tables reporting the findings from the data pool are not meant to inform educators that a certain trade book should or should not be incorporated into classroom instruction. Rather the tables help educators see which trade book from the data pool might complement another book from the data pool for the purpose of introducing students to multiple divergent 
perspectives about Andrew Jackson. The tables will also give educators an idea about which primary sources can be used to supplement the teaching of a certain trade book from the data pool. Thus, books with the most boxes checked in the tables should not necessarily be considered the best books, and books with the fewest boxes checked should not be avoided.

What makes the findings valuable are the implications they have for teachers looking to align their instruction with state and national standards. In the reading standards for literacy in history/social studies, grades sixth through eighth, in the CCSSI (2010), standard six calls for students to identify aspects of a text in order to discern an author's point of view or purpose. This includes looking for the inclusion or avoidance of particular facts. Standard nine calls for students to analyze the relationship between a primary and secondary source pertaining to the same topic (CCSSI, 2010). Teachers taking a subjective view of the books might determine that the findings from one book make it more historically accurate than a different book from the data pool. In this case, however, both books can still be regarded as invaluable teaching materials for instruction, for the teacher can introduce both books to a class and have students compare and contrast the content of the books, allowing students to identify an author's point of view or purpose (CCSSI, 2010). For example, students reading from Andrew Jackson: Our Seventh President by Gaines (2002), will read in the text that Andrew Jackson "was a racist who believed that because of the color of their skin, white people were better than blacks and Native Americans" (p. 27). Chidsey's (1976) Andrew Jackson: Hero, in contrast, stated "Jackson didn't hate Indians and didn't even despise them, as so many Tennesseans of this time did. He was not a racist, he was a realist" (p. 111). 
With nearly half of the books in the data pool intended for the intermediate grade levels, and the other half intended for the middle grade levels, teachers can choose books that meet the needs of students from different reading levels while at the same time deciding whether they want the students to be reading books that include the same content. For example, Stefoff's (1988) Andrew Jackson: $7^{\text {th }}$ President of the United States, intended for students at the middle level, and Wade"s (1993) Andrew Jackson, intended for students at the intermediate level, both mention the fact that Andrew Jackson was a slaveholder. In this situation, students coming from different ability levels of reading will still be learning Jackson's stance on slavery while reading different books.

Intended for students at the intermediate grade level, Burke's (2003) Andrew Jackson, on the other hand, does not bring up the issue of slavery or the fact that Andrew Jackson owned slaves. When this book is substituted for either of the previous two, students will be coming away with different understandings of Jackson. Through discussion with peers and the class, students can share their findings and analysis of Jackson, and learn how their understanding of Jackson can be different than the understandings of classmates as a result of which book they have read. These activities engage students in historical thinking through encountering converging and diverging perspectives in diverse texts that meet the needs of the individual students as well as teaching goals (Bickford, 2013b; Schwebel, 2011; Wineburg, 2001).

The findings from the data pool also demonstrate that different trade books diverged and converged with historians" perspectives regarding different topics within the texts. This can be seen in Gunderson's (2009) Andrew Jackson and Gaines's (2002) Andrew Jackson: Our Seventh President. Gunderson's depiction of how the Nullification 
Crisis was resolved avoided heroification in one aspect of the text; however, Andrew Jackson's views about slavery were omitted. Gaines's depiction of Jackson's views on slavery, in contrast, converged with the views of historians; however, heroification was exhibited pertaining to Jackson's involvement with resolving the Nullification Crisis. In addition to indicating that a single book from the data pool is not likely to be used effectively as a sole resource for teaching about Jackson, this finding demonstrates that books exhibited historical misrepresentations in different aspects of the texts.

Primary sources can be used to help students form a more complete understanding of Andrew Jackson and the key events he is associated with. For students having trouble putting an image to an aging Jackson that is referred to as sick and gaunt, Figures One and Two will help put the words in perspective, whereas an engraving seen in Figure Three shows Jackson in the prime of his life.

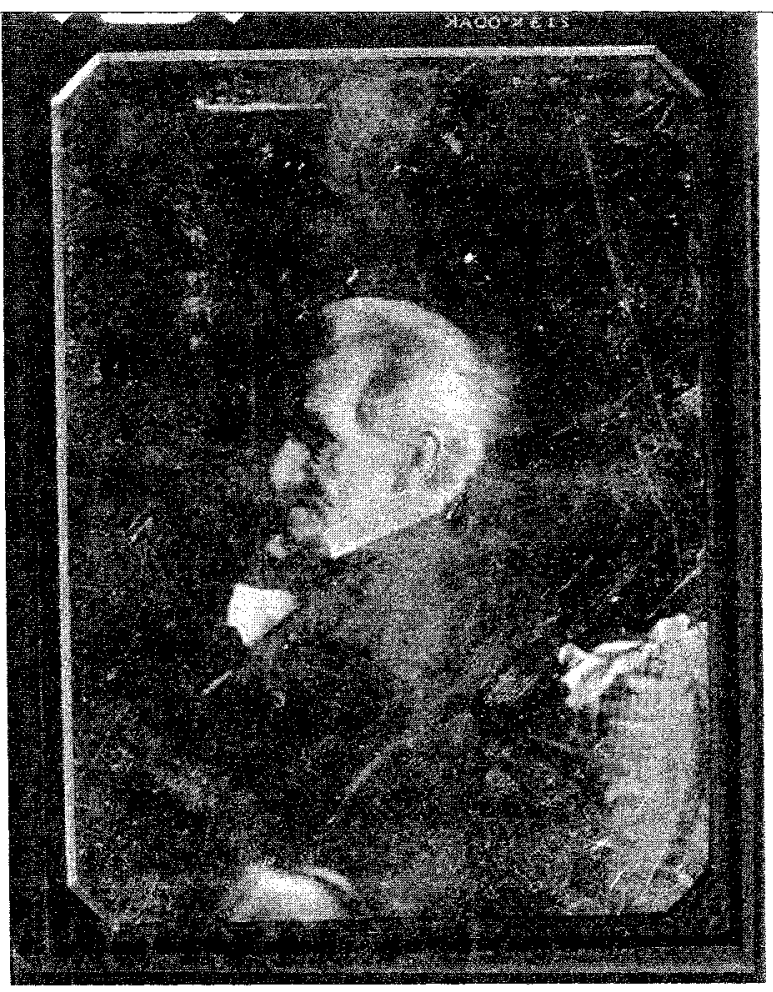


Figure 1. Anthony, Edward, photographer. "[Andrew Jackson, head-and-shoulders portrait, nearly in profile to left, leaning against pillow of which ticking appears in lower left comer.]" Daguerreotypes. Mathew Brady's studio, c1844-1845. From Library of Congress, Daguerreotype Collection.

htto://www.loc.gov/pictures/resource/cph.3g01807/ (accessed January 28, 2015).

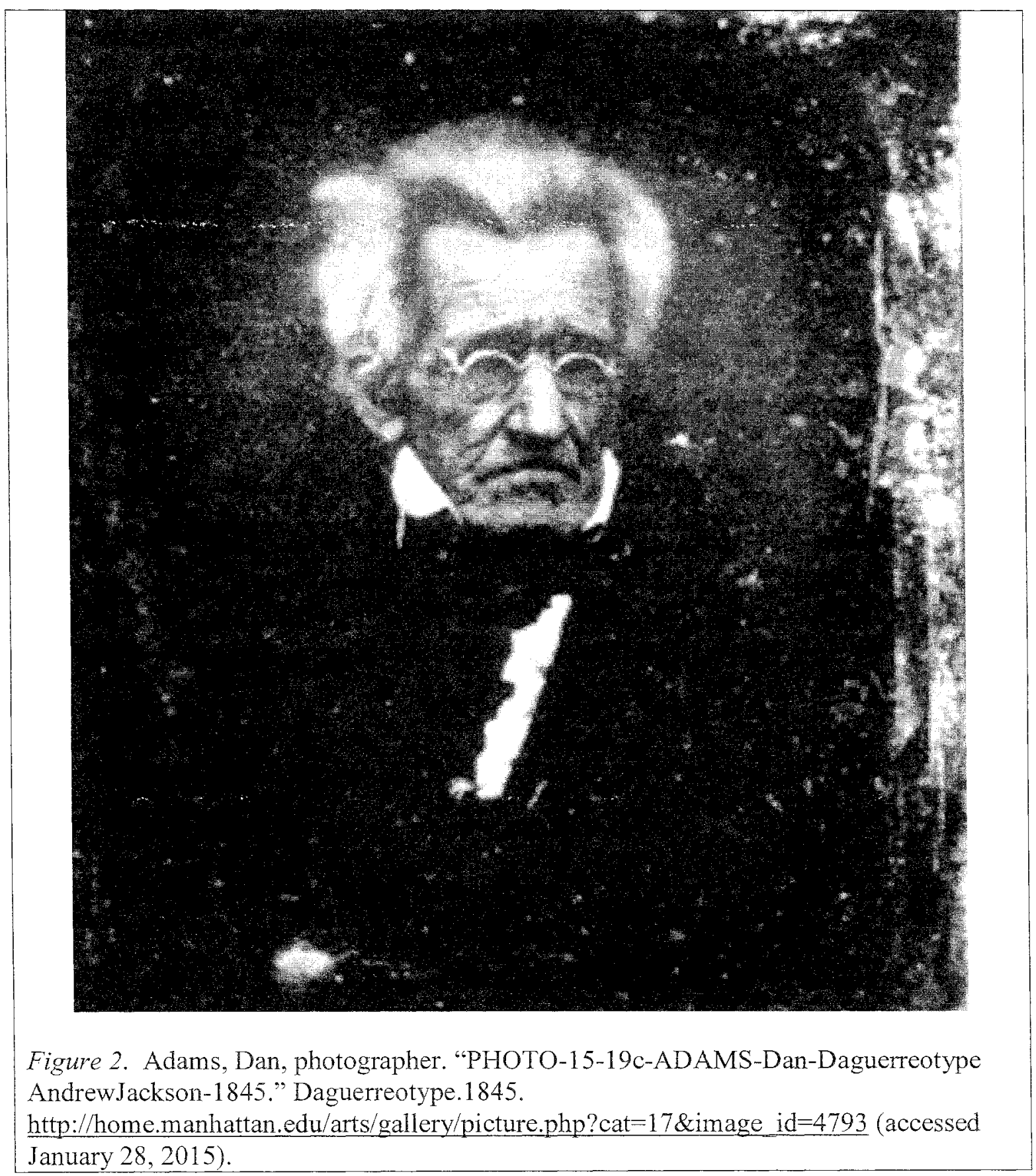




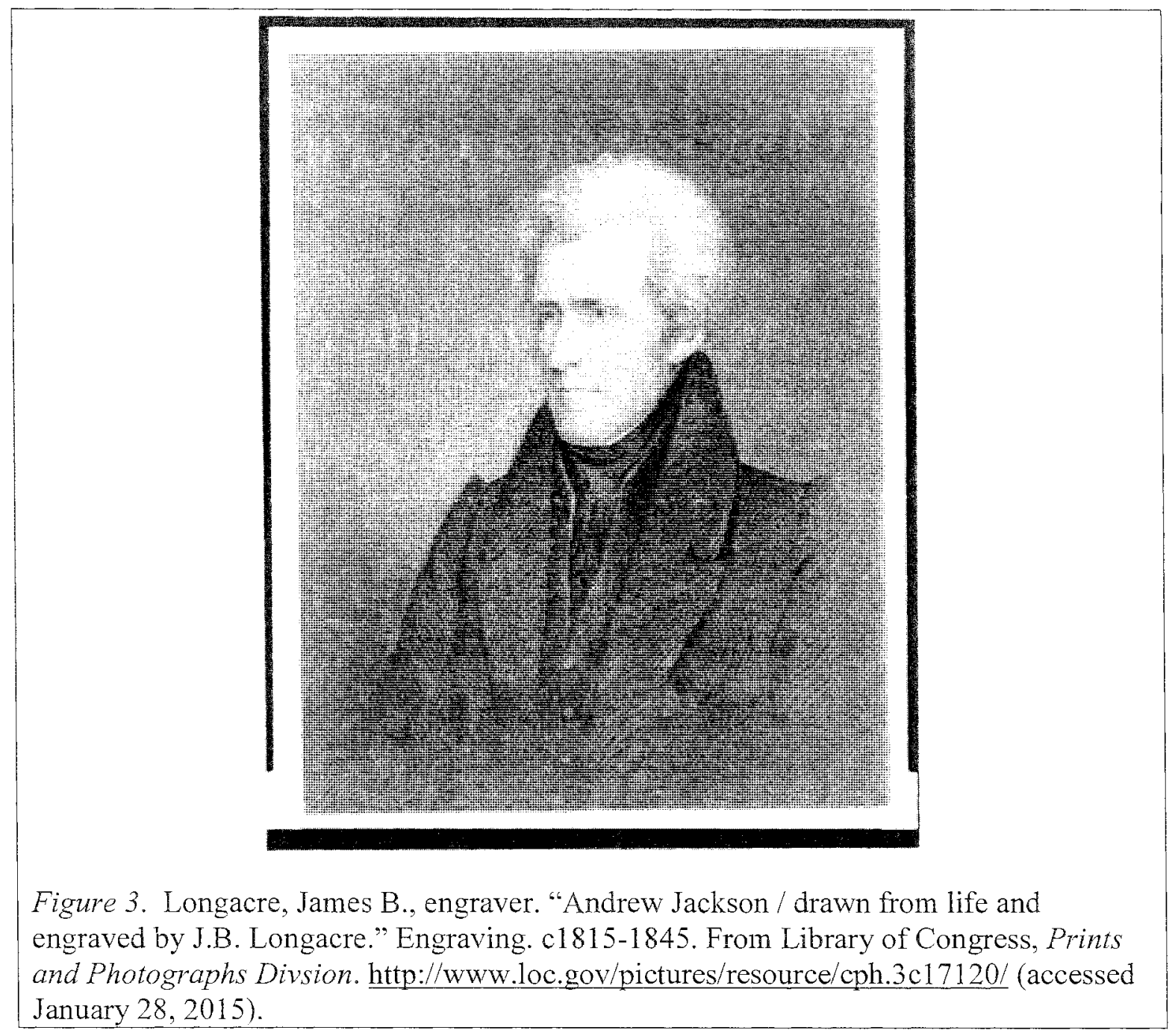

Figures Four and Five will help students see the issue of Native American removal through the lenses of Andrew Jackson and the federal government. Figure Four is a hand written message from Jackson to Congress pertaining to the removal of Native Americans, with the transcription in its entirety in Jackson's Message on Removal (Appendix C). Figure Five is the Indian Removal Act passed by Congress.

Figures Six through Ten depict how those against removal interpreted the situation. Figures Six and Seven depict a signed petition by a group of women from Ohio against removal. Figure Eight is an excerpt from a speech Senator Theodore 


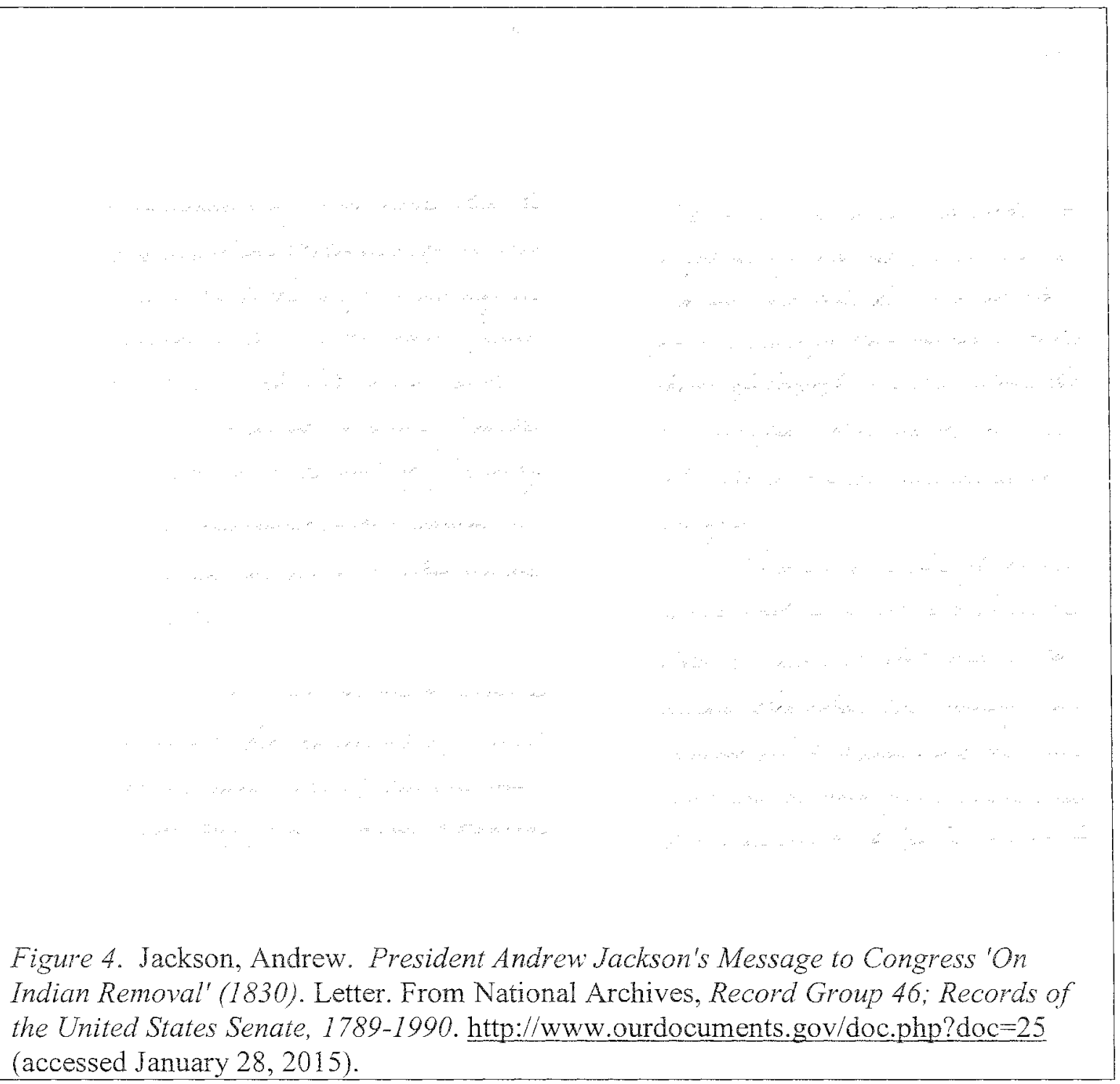

Frelinghuysen gave about the public's greed for land. Figure Nine is a petition by women of the Cherokee tribe, stating that they have done everything that was asked of them by the U.S. government in order to stay on their lands, but are being compelled to remove to the west of the Mississippi River anyway. Figure 10 depicts Andrew Jackson as a paternalistic figure to the Native Americans. 


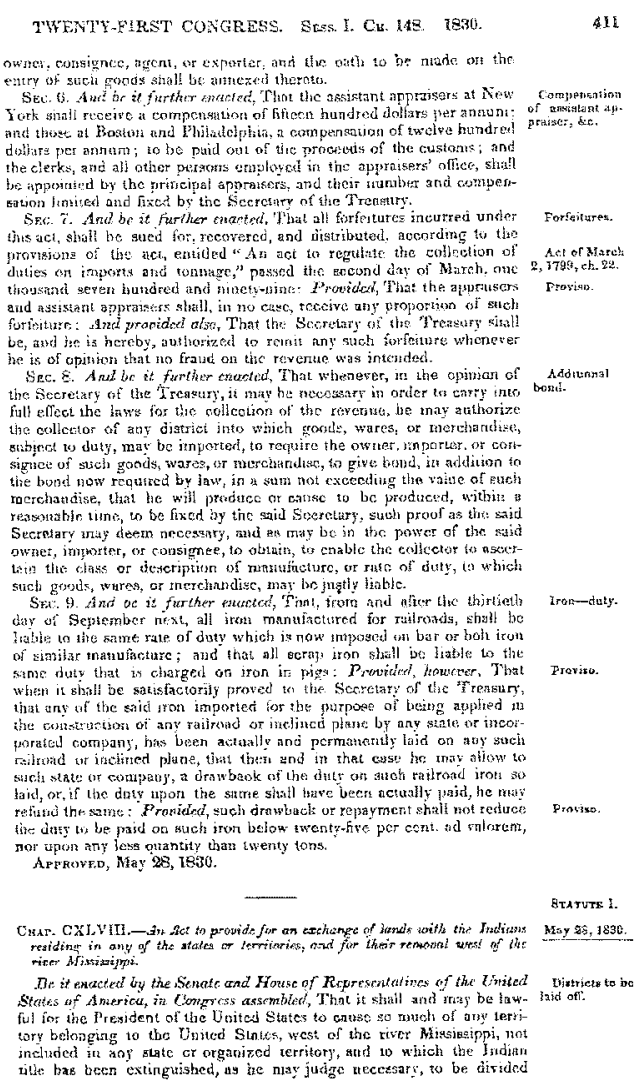

THENTYFIRST COAGRESS. Stes. I. Cu. 248. 2830

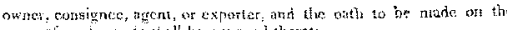

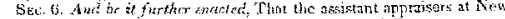

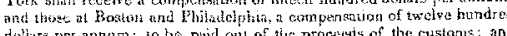

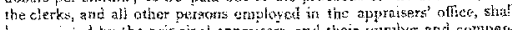

(1)

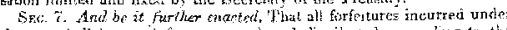

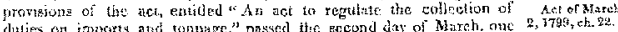

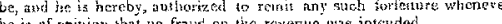

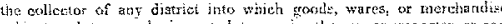

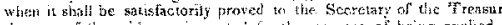

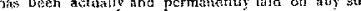

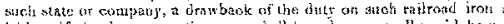

Praviso.

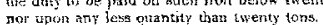

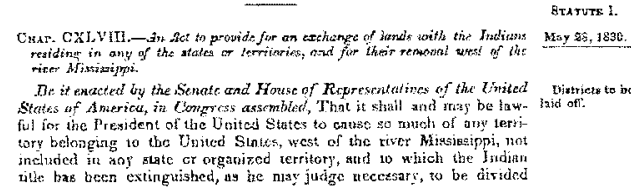

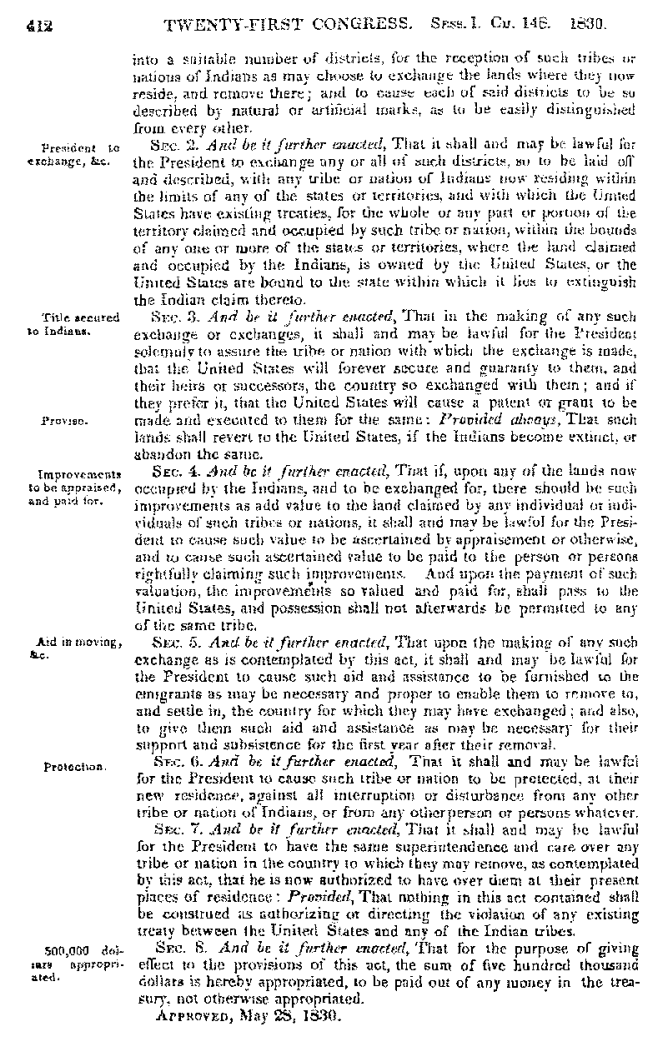

Figure 5. United States. "Chapter 148, Statute 1, May 28, 1830". The public statutes at large of the United States of America / by authority of Congress. 21st Congress, 1st Session. Boston: Charles Little and James Brown, 1845-1867 pg. 411-412. From Library of Congress, A Century of Lawmaking for a New Nation: U.S. Congressional Documents and Debates, $1774-1875$. http://memory.loc.gov/cgi-

bin/ampage? collId $=11$ sl\&fileName $=004 / 11$ s1004 $\mathrm{db} \& \mathrm{recNum}=458$ (accessed January 28, 2015).

Figures 11 and 12 give students a more candid insight into Andrew Jackson's feelings and beliefs through reading his letters. Figure 11 will have students reading Jackson's view on nullifiers and his thinking that slavery will be an emerging issue in the future. Figure 12 depicts a letter from Jackson to his wife Rachel. The contents of the letter pertain to Jackson's troubles with his soldiers as well as Jackson mentioning his adopted Native American son, whom Jackson refers to as a savage. 


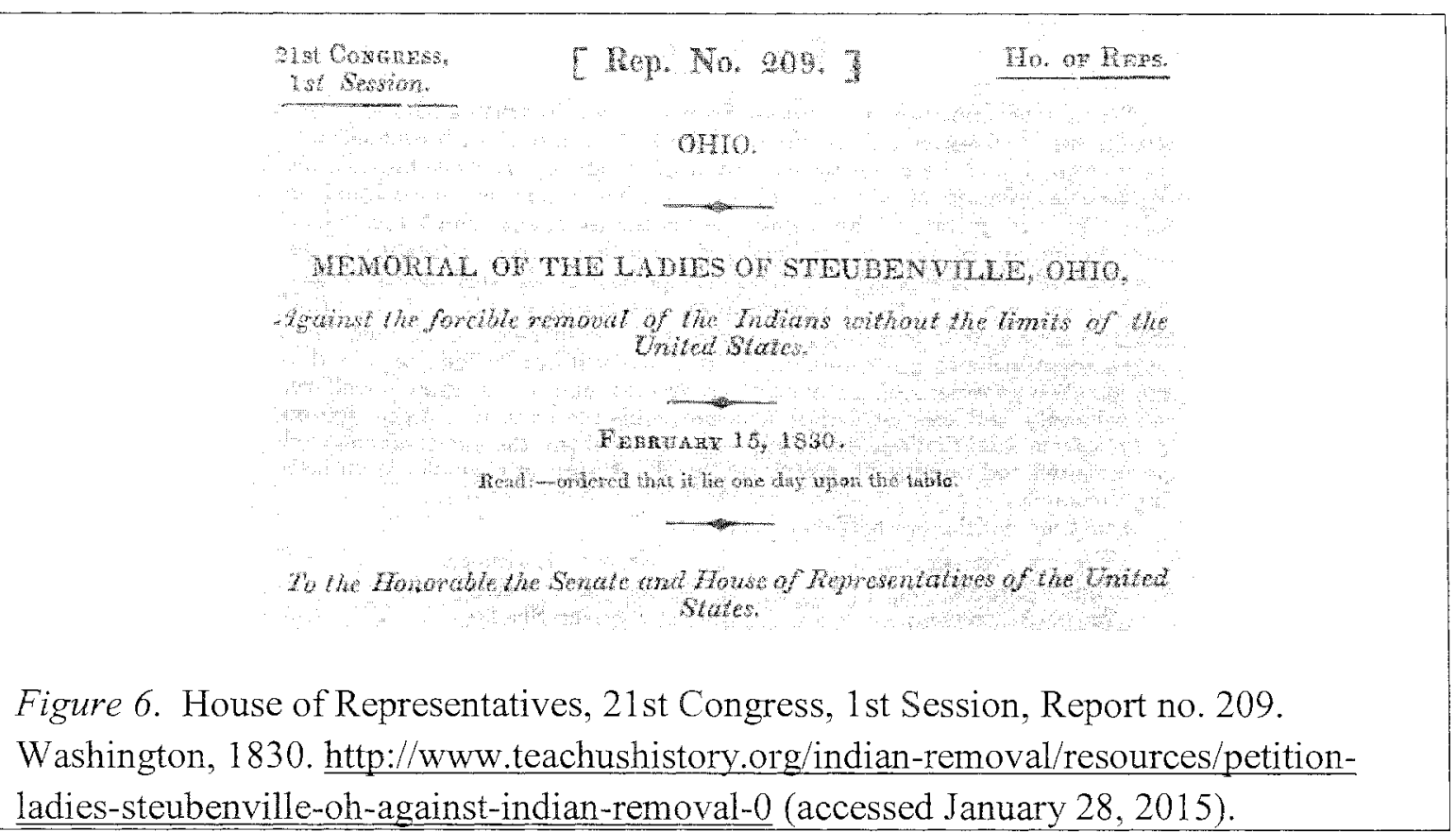

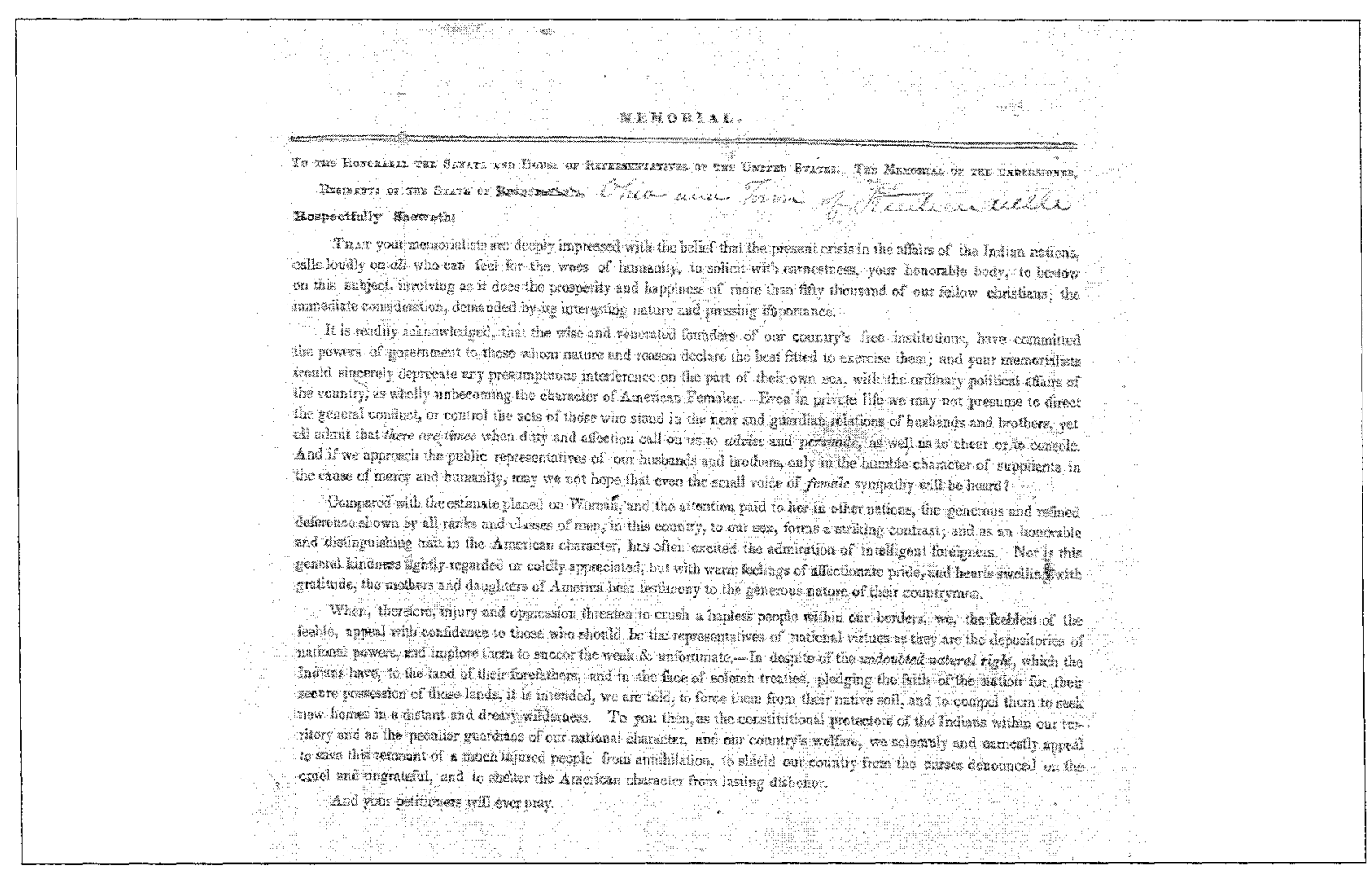




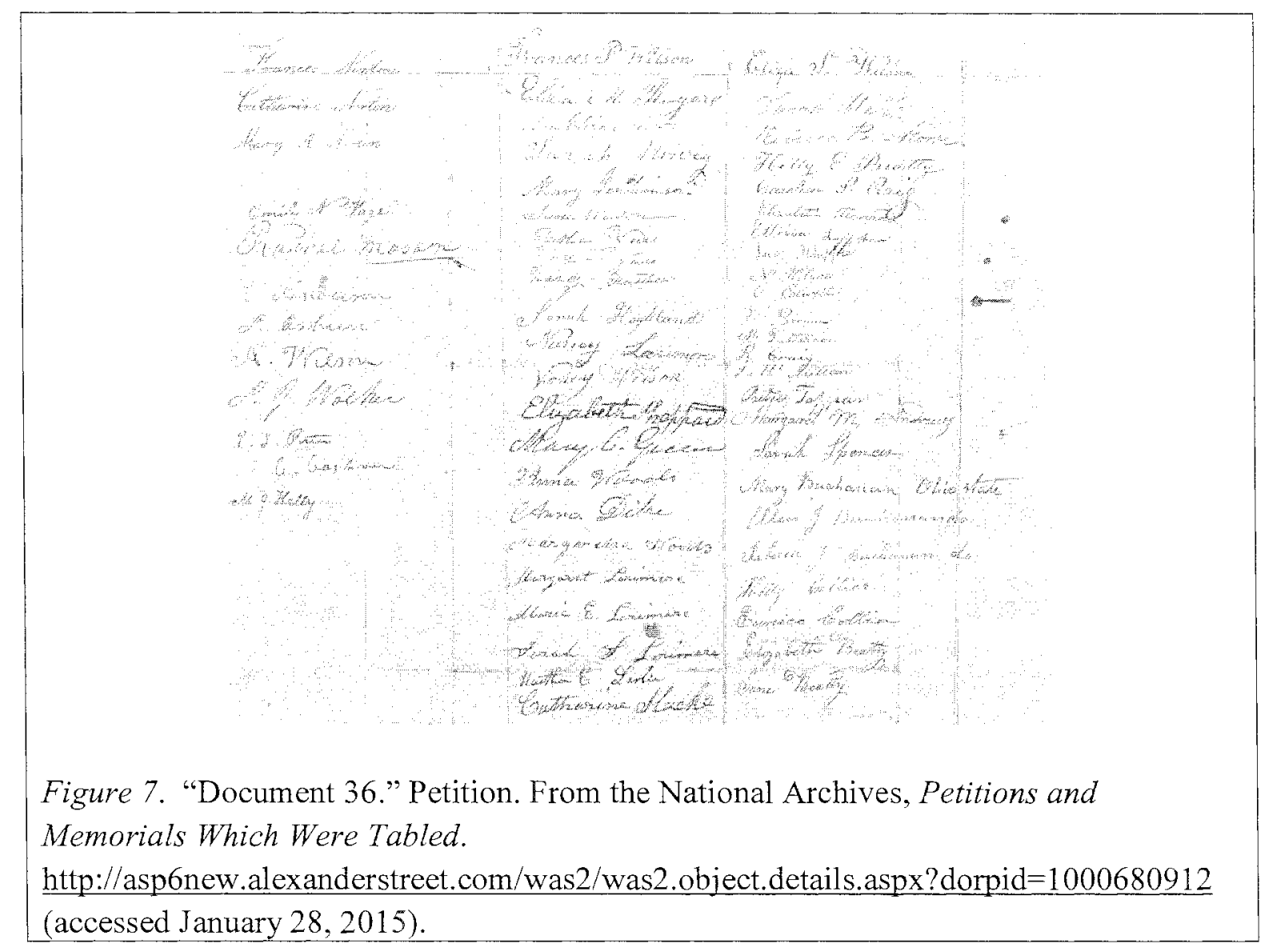

"... Several years ago, official reports to Congress stated the amount of Indian grants to the United States to exceed 214 millions of acres. Yes, sir, we have acquired, and now own, more land as the fruits of their bounty than we shall dispose of at the present rate to actual settlers in two hundred years. For, very recently, it has been ascertained, on this floor, that our public sales average not more than about one million of acres annually. It greatly aggravates the wrong that is not meditated against these tribes, to survey the rich and ample districts of their territories, that either force or persuasion have incorporated into our public domains. As the tide of our population has rolled on, we have added purchase to purchase. The confiding Indian listened to our professions of friendship: we called him brother, and he believed us. Millions after millions he has yielded to our importunity, until we have acquired more than can be cultivated in centuries--and yet we crave more. We have crowded the tribes upon a few miserable acres on our Southern frontier: it is all that is left to them of their once boundless forests: and still, like the horse-leech, our insatiated cupidity cries, give! give!..."

Figure 8. Frelinghuysen, Theodore. "Senator Frelinghuysen on Indian Removal April 9, 1830." Documents of United States Indian Policy, edited by Francis Paul Prucha, page 49. Lincoln: University of Nebraska Press, 2000. 
htp/books.google.com/books?id=COTvocv68koC\&pg=PA48\&source=gbs toc $1 \&$ cad $=4+\mathrm{v}=$ onepage $\& \mathrm{q} \& \mathrm{f}=$ false (accessed January 28,2015 ).

Beloved Children,

We have called a meeting among ourselves to consult on the different points now before the council, relating to our national affairs. We have heard with painful feelings that the bounds of the land we now possess are to be drawn into very narrow limits. The land was given to us by the Great Spirit above as our common right, to raise our children upon, \& to make support for our rising generations. We therefore humbly petition our beloved children, the head men \& warriors, to hold out to the last in support of our common right, as the Cherokee nation have been the first settlers of this land; we therefore claim the right to the soil.

We well remember that our country was formerly very extensive, but by repeated sales it has become circumscribed to the very narrow limits we have at present. Our Father the President advised us to become farmers, to manufacture our own clothes, \& to have our children instructed. To this advice we have attended in everything as far as we were able. Now the thought of being compelled to remove [to] the other side of the Mississippi is dreadful to us, because it appears to us that we, by this removal, shall be brought to a savage state again, for we have, by the endeavor of our Father the President, become too much enlightened to throw aside the privileges of a civilized life.

We therefore unanimously join in our meeting to hold our country in common as hitherto.

Some of our children have become Christians. We have missionary schools among us. We have h[e]ard the gospel in our nation. We have become civilized \& enlightened, \& are in hopes that in a few years our nation will be prepared for instruction in other branches of sciences \& arts, which are both useful \& necessary in civilized society.

There are some white men among us who have been raised in this country from their youth, are connected with us by marriage, $\&$ have considerable families, who are very active in encouraging the emigration of our nation. These ought to be our truest friends but prove our worst enemies. They seem to be only concerned how to increase their riches, but do not care what becomes of our Nation, nor even of their own wives and children.

Figure 9. Cherokee Women. Cherokee Women's Petition. Petition. From the Women and Social Movements in the United States, 1600-2000. http://asp6new.alexanderstreet.com/was2/was2.object.details.aspx?dorpid $=1000679691$ (accessed January 29, 2015). 


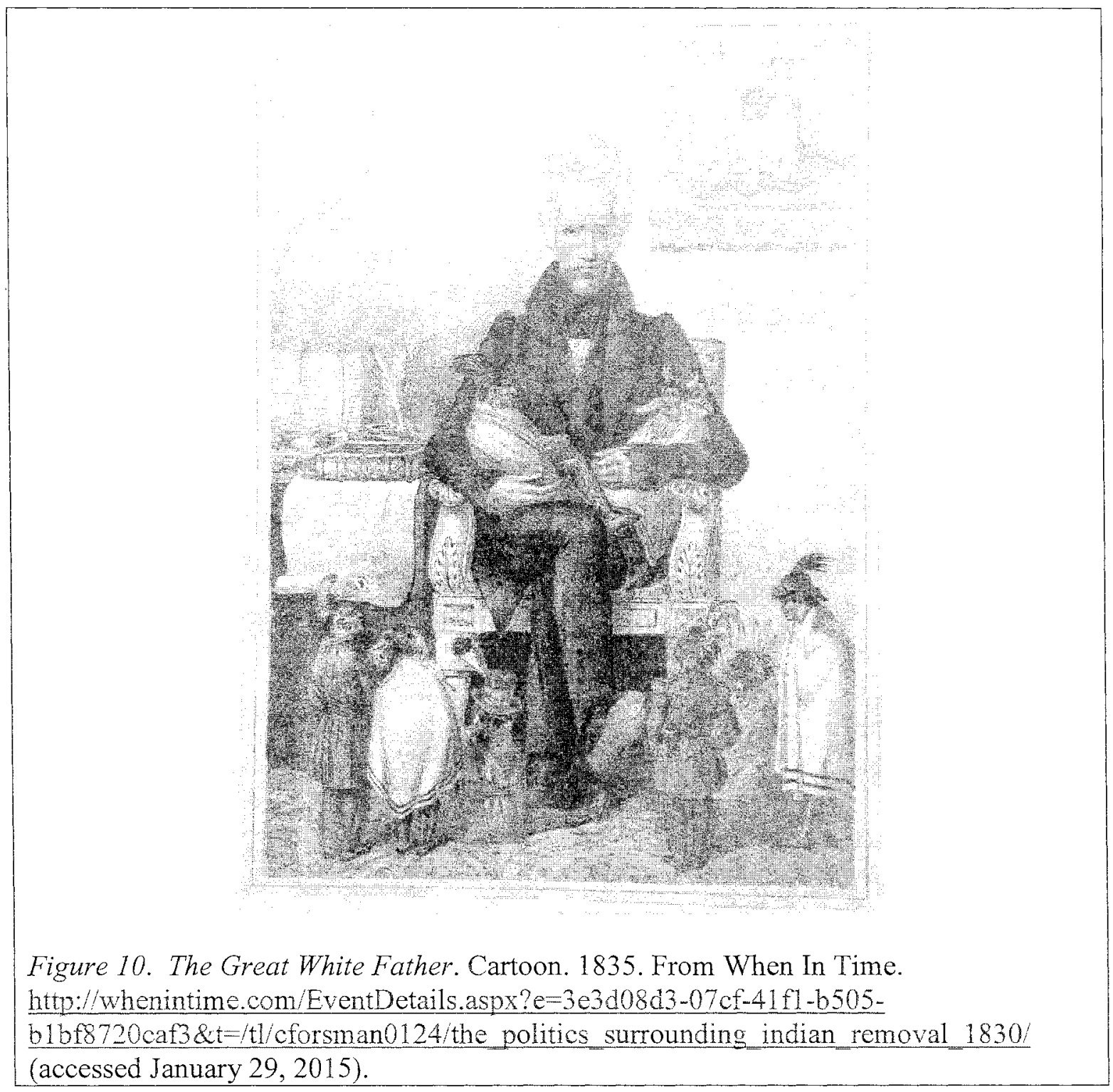

--Private--

Washington May 1st, 1833--

My Dr Sir,

I have just received your letter of the 6th ultimo, and have only time in reply to say that Genl Coffee well understood Mr. Shackleford and urged your nomination in his stead-- I had nominated you, but on the serious importunity of Col King, your Senator with, Genl Coffee the change was adopted and you nominated for the office you now fill. Before the receipt of yours Genl Coffee had written me, and requested that I would appoint you to the office vacated by Mr Shakleford -- if we had a Senate on whose principles we could 
rely, this would have been done, but I did not beleive it would be prudent to bring your name before the Senate again, and am happy you are content where you are

The Senate cannot remove you, and I am sure your faithfulness and honesty will never permit you to do an act, that will give good cause for your removal, and if Moor and Poindexter discovered that you were related to me, that would be sufficient cause, for them to reject you-- Therefore it is, that I let well enough alone, altho, I know it would be a convenience to you to be located where you are-- Still a rejection by the Senate might prove a greater inconvenience, and for the reasons assigned it was not done--

I have had a laborious task here -- but nullification is dead, and its actors \& [excitiers?] will only be remembered by the people to be execrated for their wicked designs to sever \& destroy the only good government on the Globe, and that prosperity and happiness we enjoy over every other portion of the world. Hemans gallows ought to be the fate of all such ambitious men who would involve their country in civil wars, and all the evils in its train that they might reign \& ride on its whirlwinds \& direct the Storm-- The free people of these United States have spoken, and consigned these wicked demagogues to their proper doom-- Take care of your nullifiers -- you have them amongtist you-- Let them meet with the indignant frowns of every man who loves his Country-- The tareff, it is now well known, was a mere pretext -- its burthen was on your course wollens -- by the law of July 1832 -- course woollens, was reduced to five pr cent for the benefit of the South Mr Clays bill takes it up \& classes it with woollens, at 50 percent, reduces it gradually down to 20 prcent, and there it is to remain and Mr Calhoun \& all the nullifiers agree to the principle-- The cash duties \& home valuation, will be equal to 15 prcent more, and after the year 1842 -- you pay on course wollens 35 prcent -- if this is not protection, I cannot understand -- therefore the tariff was only the pretext and disunion $\&$ a Southern confederacy the real object-- The next pretext will be the negro, or slavery question--

My health is not good, but is improving a little. present me kindly to your lady \& family, and believe me to be your friend-- I will always be happy to hear from you.

Andrew Jackson

Figure 11. Jackson, Andrew. Andrew Jackson to Andrew I. Crawford, Wednesday, May 01, 1833 (Nullification and slavery). Letter. From Library of Congress. http://memory.loc.gov/cgi-bin/query/r?ammem/mal:@field(DOCID+@lit(d0002500)) (accessed January 28, 2015).

Head quarters Fort Strother

My love

Decbr $29^{\text {th }} 1813$. $\%$ post 11 oclock at night

After twenty four hours of labour in preparing despatches for Major Genl 
Pinckney, the secratary of war and Governor Blount, during which time Major Read my aid, and myself has not slept one hour, before The dawn - (as the express is to start at day light) I take up my pen to say to you that I am well, my arm mending I hope I will be able to wear my coat sleeve on it soon I have been much pestered and vexed with the shamefull retrograde of the volunteers and mounted gunmen - and with the still more shamefull indolence of the contractors, in not supplying us with provisions - I have been anxious to advance and meet the wishes of the commander in chief by putting a speedy end to the war and return to you again, but our supplies will not justify a movement as yet - at present we have not one pound of meal but plenty of good beef and Pork - with this I tried if I could prevail on the Troops to advance but the Holston Regt. except two fine companies commanded by Capt. Hamilton and argenbright refused - five days we could have cleared the Cosa and Talleposa, and opened a communication with Genl Floyd who commands the Georgia Troops - But they did not come to fight - altho it was there complaint that they had come for that purpose and was sorry they could not have one fight that induced me to make the proposition with the supply of Beer \& pork on hand - I found it would not do and I am fearful! when I get supplies up, which I am making every exertion to do I shall have no men to fight with The shamefull desertion from their posts of the Volunteer Infantry - the violated Pledge of the cavalry \& mounted infantry under their own proper signatures, and the apathy displayed in the interior of the state by the fireside Patriotts will sink the reputation of our state - and I weep for its fall - and with it the reputation of the once brave and patriotic volunteers - who a few privations, sunk from the highest devotion of patriots - to mere, wining, complaining, sedioners and mutineers - to keep whom from open acts of mutiny I have been compelled to point my cannon against, with a lighted match to destroy them - this was agrating moment of my life - I felt the pangs of an effectionate parent, compelled from duty, to chastise his child to prevent him from destruction \& disgrace and it being his duty he shrunk not from it even when he knew death might ensue - This was a painfull moment, but it is still more painfull, to hear of their disorderly, and disgracefull conduct on their return - had I have been with them this should not have happened - what a contrast between their present return and there return last spring then they return cloathed with agood reputation, praised by all, \& what now - retreating from the field, leaving a half conquered enemy behind them within 65 miles in force, their conduct rude and disorderly - There abandonment of the service may destroy the campaign and leave our frontier again exposed to the Tomhawk of the ruthless savage - and now the return disgraced - hated and cursed by all - for there shamefull and disgracefull retrograde - no doubt you will hear of my situation being a critical and hazardous one - be not uneasy - that god that protects you at home, protects me here, and if I have trials, and Perils, he has fortified me with fortitude to do my duty under every circumstance - reguardless of consequences, and when I return, I return like a true patriot, without a tarnish on my reputation - 
I must ask you to say to feilds to have as much land cleared as he can, take care of my stock, and see that you are comfortable - if Mr Trigg of Gallatine comes for Truxton, on his shewing you my letter and in making his election as to the choic of Terms on paper you will deliver him Truxton and Dinwadie if he wants Dun, for the [ ]ason - If Mr Trigg does not call for [ ]im Capt David Smith was saying that he would take [ ]m and thought he could do well with him do my love for the best -

Please write me how my little andrew [ ] and whether, his little Indian Lyncoya was taken to him by Major Whyte of Gallatine - if he has got him now \& what he thinks of him - keep Lyncoya in the house - he is asavage [ ] that fortune has thrown in my $\mathrm{h}[\mathrm{]}$ his own femal[ ] matrons wanted to $h[$ ] because the whole race \& family of his [ ] was detroyed - I therefore want him well taken care of, he may have been given to me for some valuable purpose - in fact when I reflect that he as to his relations is so much like myself I feel an unusual sympathy for him - tell my dear little andrew to treat him well and kiss andrew for me, and with love to all friends accept the blessing of your affectionate husband

Mrs R. Jackson

P.S. two days since I sent you my famous pipe taken from the famous Bob Catala [?] by Mr Parish, keep it for my sake

Figure 12. Craven, A. O., \& Jackson, Andrew. Letters of Andrew Jackson. Berkeley: University of California Press. The Huntington Library Bulletin, No. 3, American Number (Feb., 1933), pp. 109-134. http://www.jstor.org/stable/3818190 (accessed January 28,2015 ).

Figure 13 can be used to depict how those opposed to Andrew Jackson's treatment of his soldiers felt, and how Jackson's opponents portrayed him to the public during the contentious election of 1828 . This demonstrates that though Jackson was a popular hero in the eyes of many, his actions disappointed many other people as well.

Figures 14 through 17 can be used to drive discussion about what Andrew Jackson meant to the U.S. Presidency and the American public. Figure 14 is Jackson's veto message pertaining to the Second Bank of the United States with an excerpt from the message that demonstrates Jackson's weariness with what he saw as the central 


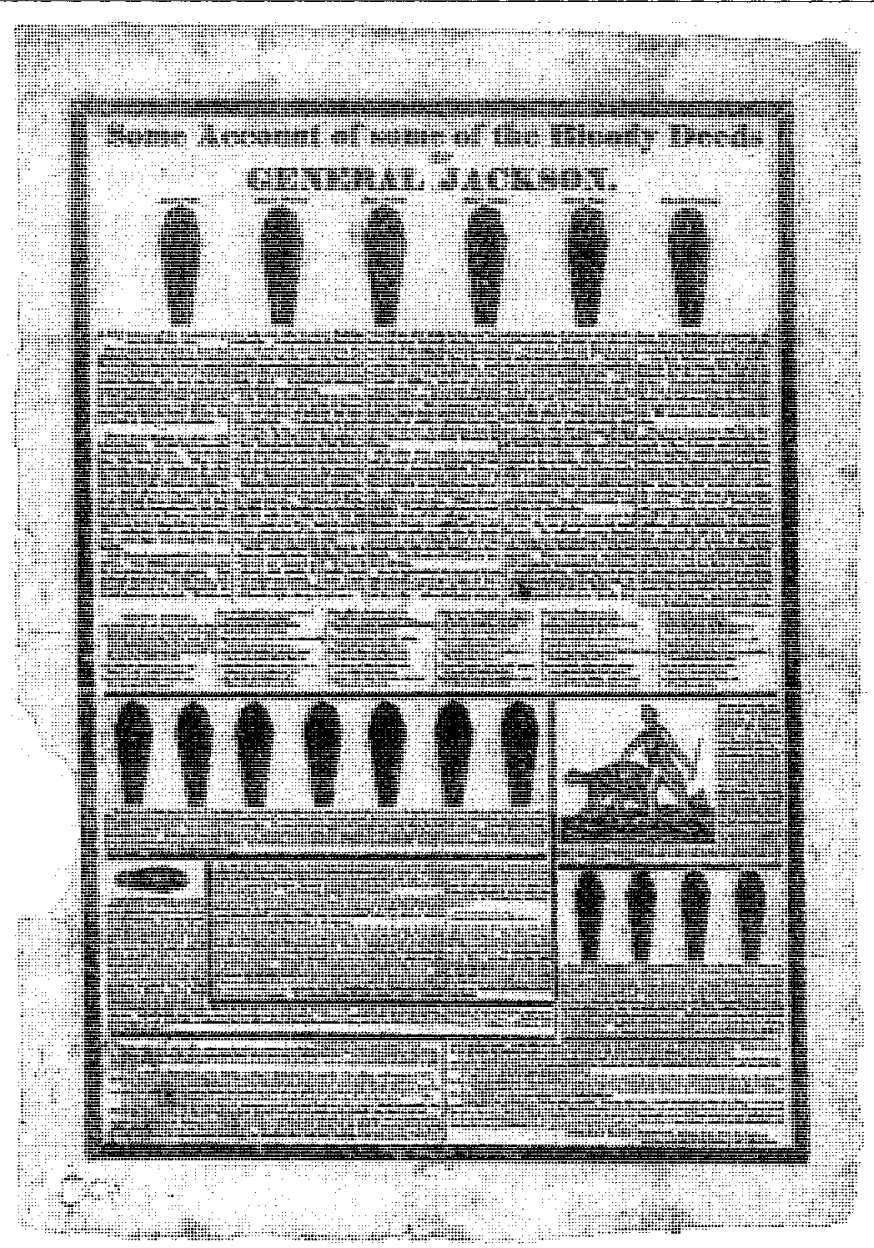

Figure 13. Binns, John. "Some account of some of the bloody deeds of General Jackson." Print. Philadelphia?: s.n., 1828. From Library of Congress: Rare Book and Special Collections Division. http://www.loc.gov/pictures/resource/cph.3a44141/ (accessed January 28, 2015).

government overreaching and abusing its powers. Figure 15 depicts Jackson battling the bank monster, and Figure 16 portrays Jackson as a king, trampling on the Constitution and keeping his veto in hand. These two aforementioned figures can be used to lead a discussion about how Jackson wielded the power of the Presidency to a degree not yet seen from a President, and not everyone agreed with his actions. Figure 17 portrays the White House being opened up for the public to attend an open house after Jackson's first inauguration ceremony. This figure can be used to show Jackson's belief in letting more 
people have access to the President, and can also be used to discuss which groups of people would have been welcomed in the White House.

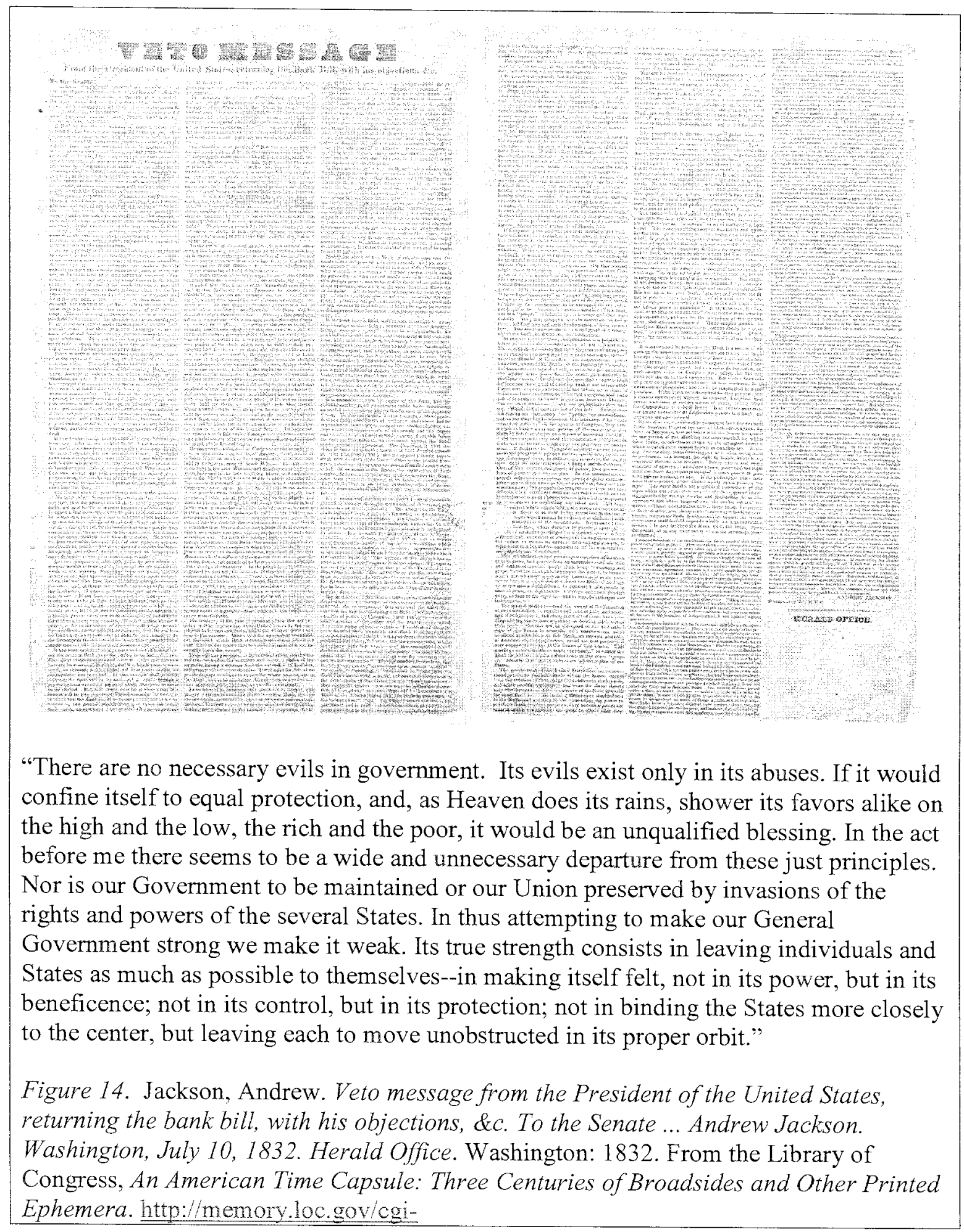


bin/query/r?ammem/AMALL:(afieldNUMBER+obandrbpe+19403000) (accessed January 29, 2015).

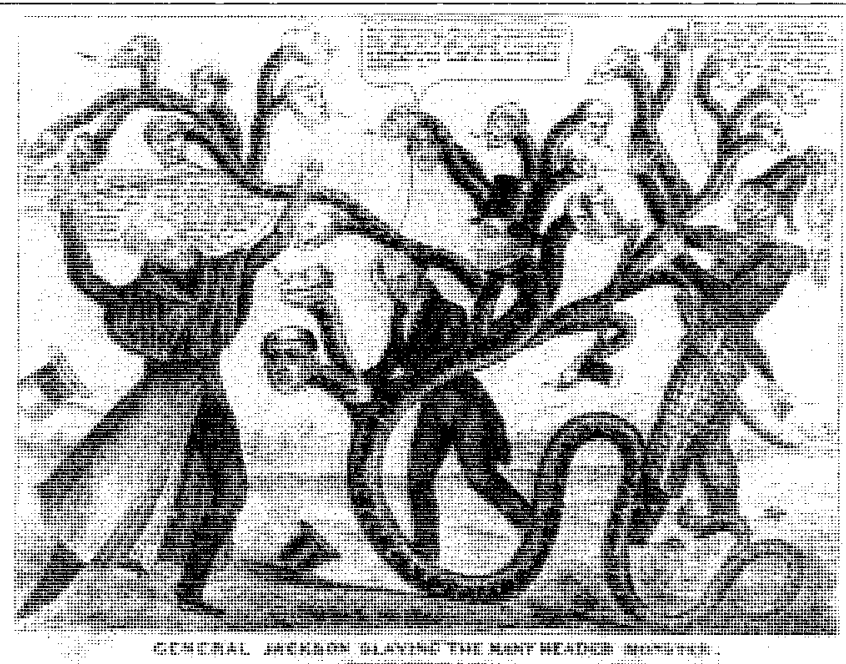

Figure 15. Robinson, Henry R., "General Jackson slaying the many headed monster." Cartoon. New York: H.R. Robinson, 1836. From Library of Congress: American Cartoon Print Filing Series. http://www.loc.gov/pictures/resource/cph.3a05364/ (accessed January 28, 2015).

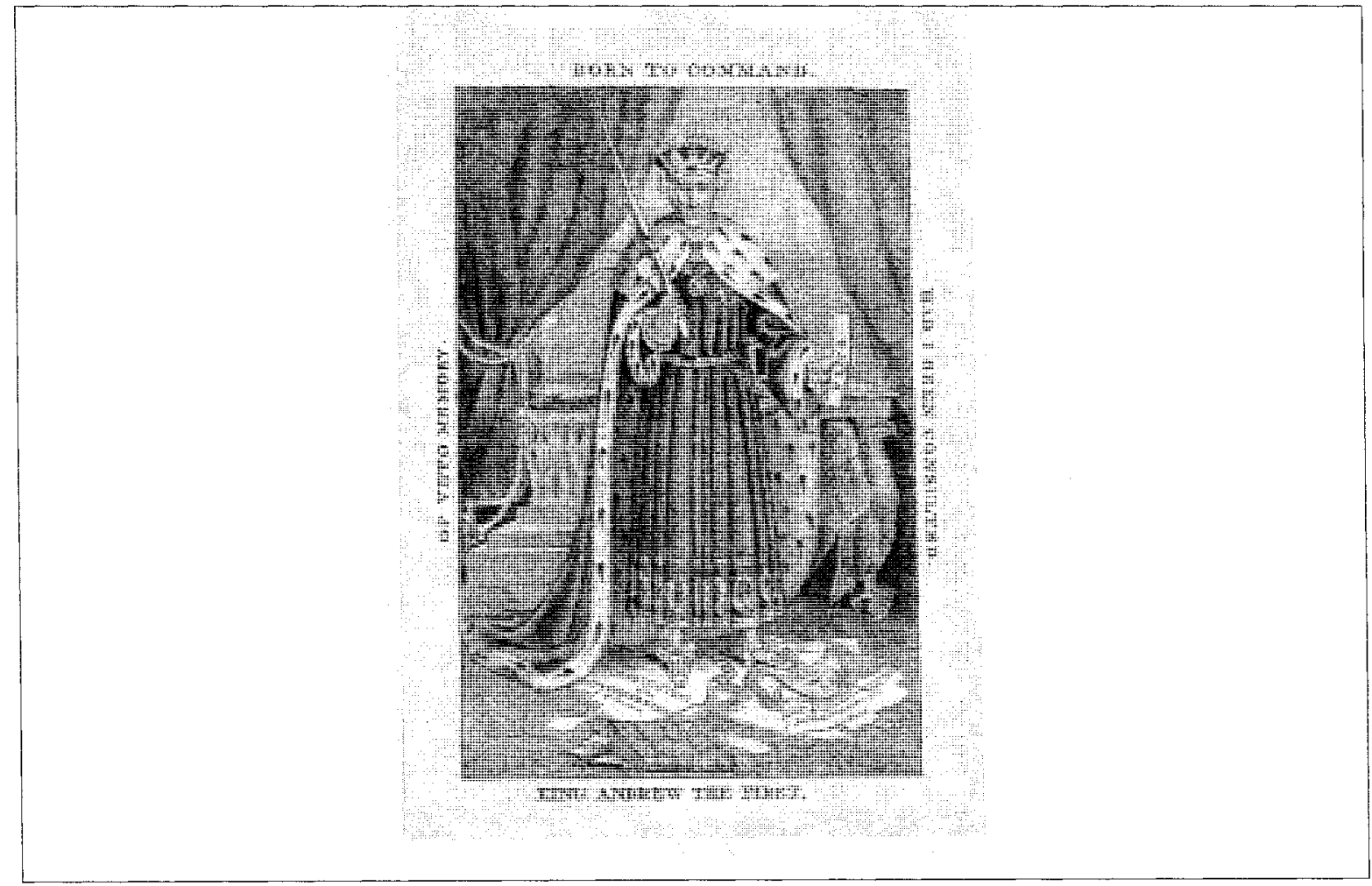


Figure 16. "King Andrew the First A political cartoon depicting Presidnet Jackson as more of a king the President." Cartoon. New York?: s.n., 1833. From Library of Congress: American Cartoon Print Filing Series.

http://www.loc.gov/pictures/resource/ppmsca.15771/ (accessed January 28, 2015).

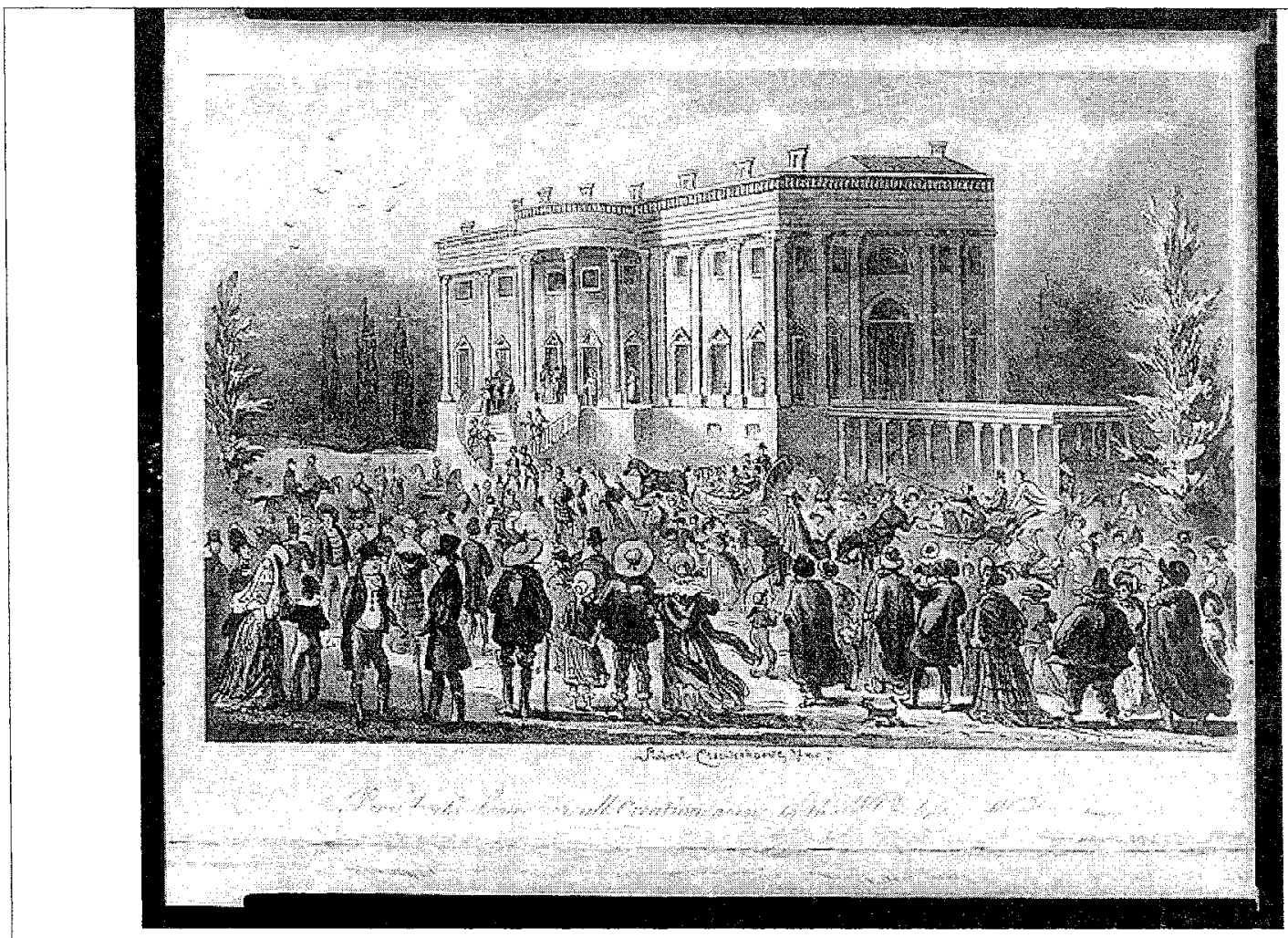

Figure 17. Cruikshank, Robert, artist. "President's Levee, or all Creation going to the White House / Robert Cruikshank fect." Print. London: Saunders and Otley, 1841. From Library of Congress: Prints and Photographs Division. http://www.loc.gov/pictures/resource/cph.3a05553/ (accessed January 28, 2015).

Figure 18 will give students an idea of the punishment Andrew Jackson believed a runaway slave deserved. This figure will offer a divergent perspective from the trade books that stated Jackson treated his slaves well, or can be used to supplement an intermediate level book that does not include Jackson's views on slavery. Figure 19 shows that Jackson's supporters presented him as a war hero and a nominee that people 
could relate to. This figure can be compared to the anti-Jackson advertised represented in

Figure 13 to show students that Jackson had both supporters and opponents.

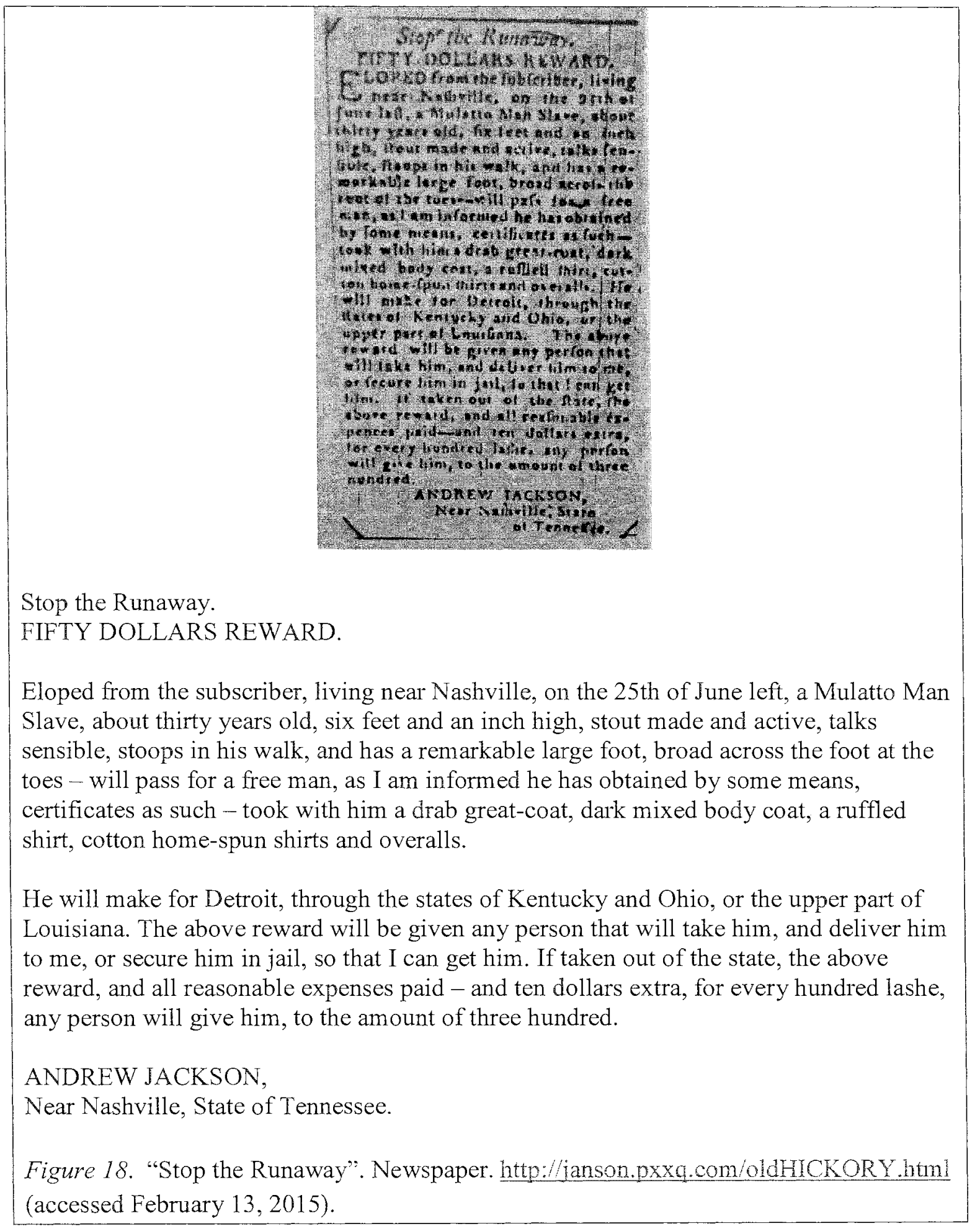




\section{Jackson Forever:

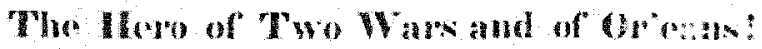 \\ Pbe Dian of the Podplat

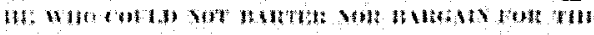

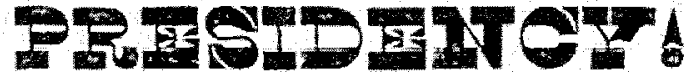

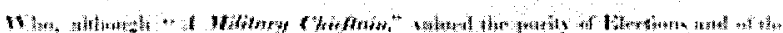 Ad

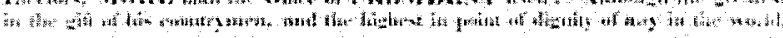

\section{BEC IUSC}

It winla bo derival from the

\section{PYOPTH:}

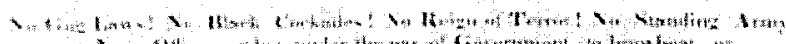

KXOCR DOW

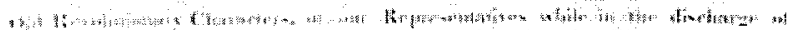

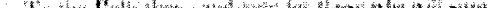

\section{ITGLOIR

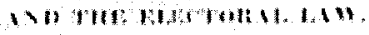

Figure 19. "Jackson Forever."

http:/rulersandleaders.com/historic documents/jackson 1828poster.htm (accessed February 13, 2015).

Students can analyze primary sources, juxtaposing them with the narratives offered by trade books from the data pool and classroom textbooks (CCSSI, 2010). For example, Figure 12 has Andrew Jackson, in his own words, telling his wife that he had to light a canon pointed at his own soldiers to quell a mutiny, and also has Jackson referring to his own adopted Native American son as a savage. Students need to look no further than Jackson's own words to be given great insight to his decisions and beliefs. Primary sources, in addition, can also be used to fill gaps of information left by the narratives of trade books. For the books from the data pool that do not include any kind of antiremoval sentiment concerning the Native Americans being forcibly removed from their lands, Figures Six through Nine will fill this gap of information. 
These primary sources represent a small sample of the many primary sources that can be found for free online through various websites, particularly the Library of Congress. It behooves any pre-service or practicing teacher wishing to foster historical thinking among students to become familiar with the resources available through the Library of Congress. Educators may wish to modify primary sources in order to make them more usable in instruction. One example of modification might include shortening the length of a primary source for use in a classroom. Figure Eight is one example of a primary source modified for length. Reading, Thinking, and Writing About History by Chancey Monte-Sano, Susan De La Paz, and Mark Felton offers modified primary sources that can serve as examples about how to modify original primary source material.

Students aware of the controversies surrounding Andrew Jackson, including his ruthlessness as a general, his views on slavery, and his decisions regarding the Second Bank of the United States, the forced removal of Native Americans to the west of the Mississippi River, invading Florida, and the Nullification Crisis are put in a situation where they have to consider the idea of leadership. What does it take to be a leader? Are the ends achieved from controversial actions worth the means it took to achieve them? These questions force students to take a stand on Jackson's character, and defend their stance against opposing viewpoints. When teachers introduce divergent perspectives from primary and secondary sources to students about these topics, students have an opportunity to form a historically representative view about Jackson. The content analysis tool used for scrutinizing the data pool for this research is recommended for educators who plan to incorporate into the classroom any future children's and young adult books written about Jackson. 


\section{Conclusion}

Though some teachers already supplement the teaching of a textbook with multiple trade books and primary sources to enhance students' understanding of history, it is now a necessity for almost every teacher to engage in this practice to align instruction with new standards. This research only further validates this necessity in that no one single trade book from the data pool is likely to deliver a comprehensive, historically accurate account of a topic in an age-appropriate manner. Trade books exhibiting historical misrepresentations, in fact, align very well with standards put forth by the CCSSI, as long as educators juxtapose such trade books with additional trade books and primary sources that introduce students to divergent perspectives. Opportunities for interdisciplinary instruction are practical as reading informational texts is stressed in the content areas. This routine of juxtaposing trade books and primary sources with the content presented in classroom textbooks can be applied to various historical figures, events, and time periods. 


\section{References}

Appleby, J., Brinkley, A., Broussard, A. J., McPherson, J. M., \& Ritchie, D. A. (2009). The American journey. Columbus, OH: The McGraw-Hill Companies, Inc.

Barksdale, S. T. (2013). Good readers make good historians: "Can we just settle it on 'a lot of people died'?" The History Teacher, 46(2), 231-252.

Bickford, J. (2013a). Examining historical (mis)representations of Christopher Columbus within children's literature. Social Studies Research and Practice, 8(2), 1-24.

Bickford, J. (2013b). Initiating historical thinking in elementary schools. Social Studies Research and Practice, 8(3), 60-77.

Bickford, J. \& Rich, C. (2014a). Examining the representation of slavery within children's literature. Social Studies Research and Practice, 9(1), 66-94.

Bickford, J. \& Rich, C. (2014b). Trade books' historical representation of Eleanor Roosevelt, Rosa Parks, and Helen Keller. Social Studies Research and Practice, $9(1), 18-65$

Chick, K. (2006). Gender balance in k-12 American history textbooks. Social Studies Research and Practice, 1(3), 284-290.

Chick, K. \& Corle, S. (2012). A gender analysis of NCSS Notable Trade Books for the intermediate grades. Social Studies Research and Practice, 7(2), 1-14.

Chick, K. \& Hong, B. (2012). Differentiated instruction in elementary social studies: Where do teachers begin? Social Studies Research and Practice, 7(3), 112-121.

Coens, T. (2013). The Early Jackson Party: A Force for Democratization. In S. P. Adams, A Companion to the Era of Andrew Jackson (231-259). West Sussex, UK: Blackwell Publishing Ltd. 
Cole, D. B. (2009). Vindicating Andrew Jackson: The 1828 election and the rise of the two-party system. Lawrence, KS: University Press of Kansas.

Common Core State Standards Initiative. (2010). Common Core state standards for English/language arts and literacy in history/social studies, science, and technical subjects. Washington, DC: Department of Education.

Davidson, J. W., \& Stoff, M. B. (2011). America: History of Our Nation. Upper Saddle River, NJ: Pearson Education, Inc.

Fitzgerald, J. (2009). Textbooks and primary source analysis. Social Studies Research and Practice, $4(3), 37-43$

Freehling, W. (1965). Prelude to the Civil War: The nullification movenent in South Carolina, 1816-1836. New York, NY: Harper \& Row Publisher, Inc.

Gannon, K. M. (2013). The Nullification Crisis. In S. P. Adams, A Companion to the Era of Andrew Jackson (376-390). West Sussex, UK: Blackwell Publishing Ltd.

Garrison, T. A. (2013). The Foundations of Jackson's Removal Policy: U.S.-Indian Relations, 1775-1815. In S. P. Adams, A Companion to the Era of Andrew Jackson (37-55). West Sussex, UK: Blackwell Publishing Ltd.

Gudmestad, R. H. (2013). Slavery and the making of the old south. In S. P. Adams, A Companion to the Era of Andrew Jackson (154-169). West Sussex, UK: Blackwell Publishing Ltd.

Hammond, B. (1957). Banks and politics in America: From the Revolution to the Civil War. Princeton, NJ: Princeton University Press. 
Henning, M., Snow-Gerono, J., Reed, D., \& Warner, A. (2006). Listening to children think critically about Christopher Columbus. Social Studies and the Young Learner, 19(2), 19-22.

Hofstadter, R. (1948). The American political tradition: And the men who made it. New York, NY: Random House.

Krippendorff, K. (2013). Content analysis: An introduction to its methodology ( $3^{\mathrm{rd}}$ ed.). Washington, DC: Sage Publishing.

Loewen, J. (2010). Teaching what really happened: How to avoid the tyranny of textbooks and get students excited about doing history. New York, NY: Teachers College Press.

Loewen, J. (1995). Lies my teacher told me: Everything your American history textbook got wrong. Ney York, NY: The New Press.

Matusevich, M. (2006). Strange bedfellows: Censorship and history textbooks. Social Studies Research and Practice, 1(3), 359-373.

Meacham, J. (2008). American Lion: Andrew Jackson in the White House. New York, NY: Random House.

Meyers, M. (1957). The Jacksonian persuasion: Politics \& belief. New York, NY: Random House.

Mihm, S. (2013). The Fog of War: Jackson, Biddle, and the Destruction of the Bank of the United States. In S. P. Adams, A Companion to the Era of Andrew Jackson (48-375). West Sussex, UK: Blackwell Publishing Ltd. 
Murphy, S. A. (2013). The Myth and Reality of Andrew Jackson's Rise in the Election of 1824. In S. P. Adams, A Companion to the Era of Andrew Jackson (260-279). West Sussex, UK: Blackwell Publishing Ltd.

National Council for the Social Studies. (2013). College, career, and civic life (C3) framework for social studies state standards: Guidelines for enhancing the rigor of $k-12$ civics, economics, geography, and history. Silver Spring, MD: NCSS.

Newman, S. B., \& Roskos, K. (2013). Why common core matters: What parents need to know. The Reading Teacher, 67(1), 9-11.

Nokes, J. D. (2011). Recognizing and addressing the barriers to adolescents" "reading like historians". The History Teacher, 44(3), 379-399.

Partnership for Assessment of Readiness for College and Careers. (2012). PARCC model content frameworks for English language arts/literacy. Washington, DC: Department of Education.

Prucha, F. P. (1969). Andrew Jackson's Indian policy: A reassessment. Journal of American History 56 (3), 527-539.

Remini, R. V. (2001). Andrew Jackson and his Indian wars. New York, NY: Penguin Group.

Remini, R. V. (1988a). The legacy of Andrew Jackson. Baton Rouge, LA: Louisiana State University Press.

Remini, R. V. (1988b). The life of Andrew Jackson. New York, NY: Penguin Books.

Remini, R. V. (1967). Andrew Jackson and the bank war: A Study in the Growth of Presidential Power. New York, NY: W. W. Norton \& Company. 
Rogin, M. P. (1975). Fathers and children: Andrew Jackson and the subjugation of the American Indian. New York, NY: Random House, Inc.

Sacher, J. M. (2013). The Elections of 1824 and 1828 and the Birth of Modern Politics. In S. P. Adams, A Companion to the Era of Andrew Jackson (280-297). West Sussex, UK: Blackwell Publishing Ltd.

Sapers, J. (2015 February 26). Common Core's unintended consequences? More teachers write their own curricula. The Hechinger Report: Covering Innovation and Inequality in Education. Retrieved from http:/hechingerreport.org/commoncores-unintended-consequence/

Schlesinger, Jr., A. M. (1946). The age of Jackson. Boston, MA: Little, Brown and Company.

Schwebel, S. L. (2011). Child-sized history: Fictions of the past in U.S. classrooms. Nashville, TN: Vanderbilt University Press.

Sellers, C. (1991). The market revolution. New York, NY: Oxford University Press.

Sewall, G. T. (2000). History Textbooks at the New Century. Retrieved from http:/www.historytextbooks.org/reports.htm.

Wallace, A. F. C. (1993). The long, bitter trail: Andrew Jackson and the Indians. New York, NY: Hill and Wang.

Warshauer, M. (2013). The Legacy of the Battle of New Orleans. In S. P. Adams, A Companion to the Era of Andrew Jackson (79-92). West Sussex, UK: Blackwell Publishing Ltd.

Wilentz, S. (2005). The rise of American democracy: Jefferson to Lincoln. New York, NY: W. W. Norton \& Company, Inc. 
Williams, T. (2009). "A closer look: The representation of slavery in the Dear America. series." Social Studies and the Young Learner, 21(3), 26-29.

Wineburg, S. (2001). Historical thinking and other unnatural acts: Charting the future of teaching the past. Philadelphia, PA: Temple University Press.

Zakim, M. (2013). Creating a democracy of common men. In S. P. Adams, A Companion to the Era of Andrew Jackson (170-193). West Sussex, UK: Blackwell Publishing Ltd. 
Appendix $A$

Trade Books on Andrew Jackson

Behrman, C. H. (2003). Andrew Jackson. Minneapolis, MN: Lemer Publications Company.

Burke, R. (2003). Andrew Jackson. Chicago, IL: Heinemann Library.

Chidsey, D. B. (1976). Andrew Jackson: Hero. Nashville, TN: Thomas Nelson INC., Publishers.

Coit, M. (1965). Andrew Jackson. Boston, MA: Houghton Mifflin Company Boston. Collier, C., \& Collier, I. L. (1999). Andrew Jackson's America: 1824-1850. New York, NY: Benchmark Books.

Doherty, K. (2003). Andrew Jackson. Danbury, CT: Children's Press.

Feinstein, S. (2002). Andrew Jackson: A MyReportLinks.com book. Berkeley Heights, NJ: Enslow Publishers, Inc.

Gaines, A. G. (2002). Andrew Jackson: Our seventh President. Chanhassen, MN: The Child's World, Inc.

Gunderson, M. M. (2009). Andrew Jackson. Edina, MN: ABDO Publishing Company. Gutman, W. (1987). Andrew Jackson and the new populism. Hauppauge, NY: Barron's Educational Series, Inc.

Harmon, D. E. (2003). Andrew Jackson. Broomall, PA: Mason Crest Publishers. Hilton, S. (1988). The World of Andrew Jackson. New York, NY: Walker Publishing Company, Inc.

Judson, K. (1997). Andrew Jackson. Springfield, NJ: Enslow Publishers, Inc. 
Kay Jr., O. (1967). Meet Andrew Jackson. New York, NY: Random House, Inc.

Martin, P. M. (1966). Andrew Jackson. New York, NY: G.P. Putnam's Sons.

Meltzer, M. (1993). Andrew Jackson and his America. New York, NY: Franklin Watts.

Osinski, A. (1987). Andrew Jackson: Seventh President of the United States. Chicago, IL: Childrens Press.

Parlin, J. (1991). Andrew Jackson: Pioneer and President. New York, NY: Chelsea House Publishers.

Potts, S. (1996). Andrew Jackson. Mankato, MN: Bridgestone Books.

Quackenbush, R. (1986). Who let muddy boots into the White House: A story of Andrew Jackson. New York, NY: Simon \& Schuster Inc.

Sabin, L. (1986). Andrew Jackson: Frontier patriot. Mahwah, NJ: Troll Associates. Sandak, C. R. (1992). The Jacksons. New York, NY: Crestwood House.

Somervill, B. (2003). Andrew Jackson. Minneapolis, MN: Compass Point Books. Stefoff, R. (1988). Andrew Jackson: $7^{\text {th }}$ President of the United States. Ada, OK: Garret Educational Corporation.

Venezia, M. (2005). Andrew Jackson: Seventh President. Danbury, CT: Children's Press. Viola, H. J. (1986). Andrew Jackson. New York, NY: Cheisea House Publishers.

Wade, L. (1993). Andrew Jackson. Unknown: January Productions Inc.

Welsbacher, A. (1990). Andrew Jackson. Edina, MN: ABDO Publishing Company. Whitelaw, N. (2001). Andrew Jackson: Frontier President. Greensboro, NC: Morgan Reynolds, Ine. 


\section{Appendix $B$}

\section{Content Analysis Tool}

1. Author Name:

2. Book Title:

3. Publication Date:

4. Series Title:

5. Reprint Dates:

6. Intended grade level of the book:

7. Is the narrative presented as historical fiction or historical non-fiction (narrative nonfiction, expository, biography), or mixed-genre?

8. Would the genre and/or level of factual basis be obvious to a typical reader of the intended grade?

9. Did the book incorporate primary sources? If so, how?

10. What time frames of Jackson's life does the book cover?
a. Youth:
b. Life on Frontier:
c. Military Career:
d. U.S. Presidency:
e. Life Post-Presidency:

11. Did the author contextualize frontier life during Jackson's time as a child through his formative years? If so, how?

12. Did the author depict Jackson's views on slavery? If so, how?

13. Did the author depict violence during Jackson's military career when Jackson was dealing with his soldiers and punishing enemies? If so, how?

14. Were Native Americans included in the narrative? If so, how?

15. Did the author refer to the population as "Native Americans", "Indians", or "American Indians"?

16. Did the author depict the differences between Jackson and the U.S. Presidents that served before him? If so, how?

17. Did the author use the term Jacksonian Democracy? If so, how did the author define the term?

18. Did the author depict Jackson's rationale for important decisions? If so, how?
a. Invading Florida:
b. Native American Removal:
c. Nullification Crisis:
d. Bank War:

19. Did the author portray the Washington establishment's perceptions of Jackson? If so, how?

20. Did the author portray Jackson as having a bad temper? If so, how?

21. Did the author depict Jackson's health problems throughout his life? If so, how?

22. Did the author use the term "common people" or "common man"? If so, how did the author define the term?

23. Were any common historical misrepresentations apparent? If so, describe. 
a. Presentism:

b. Exceptionalism:

c. Villainification:

d. Heroification:

e. Omission:

24. Were there any parts of the book that seemed historically inaccurate or problematic? If so, describe.

25. Additional comments:

Coding guidelines are as follows:

- Explicit/Detailed (The topic is explicitly included in two or more sentences with at least one sentence in the narrative and the other sentence could be in the Foreword or Afterword.)

- Explicit/Minimized (The topic is explicitly included in one sentence in either the Foreword, narrative, or Afterword.)

- Implicit/Vague (The topic is implicitly included in the Foreword, narrative, or Afterword.) 
Appendix C

\section{Jackson's Message on Removal}

"It gives me pleasure to announce to Congress that the benevolent policy of the Government, steadily pursued for nearly thirty years, in relation to the removal of the Indians beyond the white settiements is approaching to a happy consummation. Two important tribes have accepted the provision made for their removal at the last session of Congress, and it is believed that their example will induce the remaining tribes also to seek the same obvious advantages. The consequences of a speedy removal will be important to the United States, to individual States, and to the Indians themselves. The pecuniary advantages which it promises to the Government are the least of its recommendations. It puts an end to all possible danger of collision between the authorities of the General and State Governments on account of the Indians. It will place a dense and civilized population in large tracts of country now occupied by a few savage hunters. By opening the whole territory between Tennessee on the north and Louisiana on the south to the settlement of the whites it will incalculably strengthen the southwestern frontier and render the adjacent States strong enough to repel future invasions without remote aid. It will relieve the whole State of Mississippi and the western part of Alabama of Indian occupancy, and enable those States to advance rapidly in population, wealth, and power. It will separate the Indians from immediate contact with settlements of whites; free them from the power of the States; enable them to pursue happiness in their own way and under their own rude institutions; will retard the progress of decay, which is lessening their numbers, and perhaps cause them gradually, under the protection of the Government and through the influence of good counsels, to cast off their savage habits and become an interesting, civilized, and Christian community.

What good man would prefer a country covered with forests and ranged by a few thousand savages to our extensive Republic, studded with cities, towns, and prosperous farms embellished with all the improvements which art can devise or industry execute, occupied by more than 12,000,000 happy people, and filled with all the blessings of liberty, civilization and religion?

The present policy of the Government is but a continuation of the same progressive change by a milder process. The tribes which occupied the countries now constituting the Eastern States were annihilated or have melted away to make room for the whites. The waves of population and civilization are rolling to the westward, and we now propose to acquire the countries occupied by the red men of the South and West by a fair exchange, and, at the expense of the United States, to send them to land where their existence may be prolonged and perhaps made perpetual. Doubtless it will be painful to leave the graves of their fathers; but what do they more than our ancestors did or than our children are now doing? To better their condition in an unknown land our forefathers left all that was dear in earthly objects. Our children by thousands yearly leave the land of their birth to seek new homes in distant regions. Does Humanity weep at these painful separations from everything, animate and inanimate, with which the young heart has become 
entwined? Far from it. It is rather a source of joy that our country affords scope where our young population may range unconstrained in body or in mind, developing the power and facilities of man in their highest perfection. These remove hundreds and almost thousands of miles at their own expense, purchase the lands they occupy, and support themselves at their new homes from the moment of their arrival. Can it be cruel in this Government when, by events which it can not control, the Indian is made discontented in his ancient home to purchase his lands, to give him a new and extensive territory, to pay the expense of his removal, and support him a year in his new abode? How many thousands of our own people would gladly embrace the opportunity of removing to the West on such conditions! If the offers made to the Indians were extended to them, they would be hailed with gratitude and joy.

And is it supposed that the wandering savage has a stronger attachment to his home than the settled, civilized Christian? Is it more afflicting to him to leave the graves of his fathers than it is to our brothers and children? Rightly considered, the policy of the General Government toward the red man is not only liberal, but generous. He is unwilling to submit to the laws of the States and mingle with their population. To save him from this alternative, or perhaps utter annihilation, the General Government kindly offers him a new home, and proposes to pay the whole expense of his removal and settlement."

Jackson, Andrew. President Andrew Jackson's Message to Congress 'On Indian Removal' (1830). Letter. From National Archives, Record Group 46; Records of the United States Senate, 1789-1990. http://www.ourdocuments.gov/doc.php?doc=25 (accessed January 28, 2015). 